\title{
A Discernment of Two Opposing Reports on the Hydrological Effects of a Hydrothermal Power Plant
}

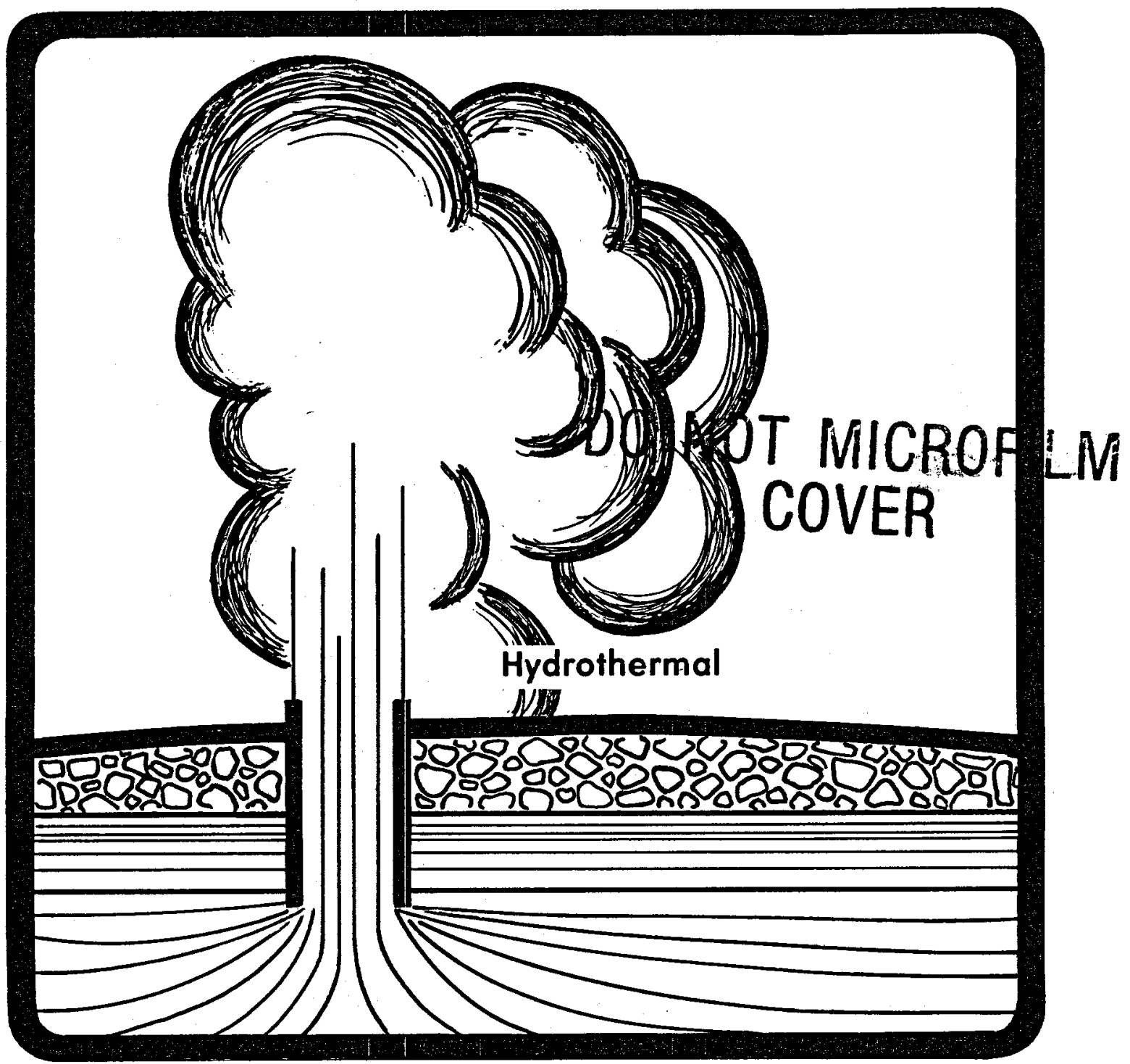

Los Alamos National Laborafory is operated by the 'University of Callfornia for the United States Department of Energy under contract W-7405-ENG-36.

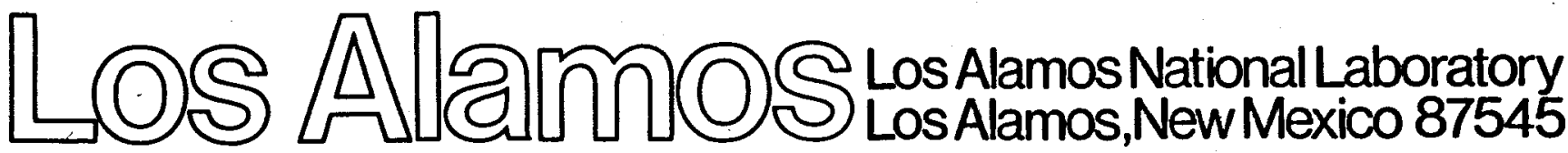




\section{DISCLAIMER}

This report was prepared as an account of work sponsored by an agency of the United States Government. Neither the United States Government nor any agency Thereof, nor any of their employees, makes any warranty, express or implied, or assumes any legal liability or responsibility for the accuracy, completeness, or usefulness of any information, apparatus, product, or process disclosed, or represents that its use would not infringe privately owned rights. Reference herein to any specific commercial product, process, or service by trade name, trademark, manufacturer, or otherwise does not necessarily constitute or imply its endorsement, recommendation, or favoring by the United States Government or any agency thereof. The views and opinions of authors expressed herein do not necessarily state or reflect those of the United States Government or any agency thereof. 


\section{DISCLAIMER}

Portions of this document may be illegible in electronic image products. Images are produced from the best available original document. 


\section{DO NOT MICROFILM THIS PAGE}

This work was supported by the U.S. Department of Energy, Assistant Secretary for Environment, Frank P. Hudson, Contract Officer.

Photocomposition by Joyce A. Martinez

Manuscript prepared by Maxine Lewis

\section{DISCLAIMER}

This report was prepared as an account of work sponsored by an agency of the United States Government. Neither the United States Government nor any agency thereof, nor any of their employees, makes any warranty, express or implied, or assumes any legal liability or responsibility for the accuracy, completeness, or usefulness of any information, apparatus, product, or process disclosed, or represents that its use would not infringe privately owned rights. Reference herein to any specific commercial product, process, or service by trade name, trademark, manufacturer, or otherwise, does not necessarily constitute or imply its endorsement, recommendation, or favoring by the United States Government or any agency thereof. The views and opinions of authors expressed herein do not necessarily state or reflect those of the United States Government or any agency thereof. 
LA--10691-MS

DE86 012745
LA-10691-MS

UC-66e

Issued: June 1986

\section{A Discernment of Two Opposing Reports on the Hydrological Effects of a Hydrothermal Power Plant}

Joel M. Williams

Prepared for the

U.S. Department of Energy

Director of Energy Research

Office of Health and Environmental Research

Washington, D.C. 


\section{DISCLAIMER}

This report was prepared as an account of work sponsored by an agency of the United States Government. Neither the United States Government nor any agency thereof, nor any of their employees, makes any warranty, express or implied, or assumes any legal liability or responsibility for the accuracy, completeness, or usefulness of any information, apparatus, product, or process disclosed, or represents that its use would not infringe privately owned rights. Refer- ence herein to any specific commercial product, process, or service by trade name, trademark, manufacturer, or otherwise does not necessarily constitute or imply its endorsement, recommendation, or favoring by the United States Government or any agency thereof. The views and opinions of authors expressed herein do not necessarily state or reflect those of the United States Government or any agency thereof. 


\title{
A DISCERNMENT OF TWO OPPOSING REPORTS ON \\ THE HYDROLOGICAL EFFECTS OF A HYDROTHERMAL POWER PLANT
}

\author{
by
}

Joel M. Williams

\begin{abstract}
Two evaluations to determine the hydrological effects of a 50-megawatt hydrothermal power plant in the Jemez Mountains give dramatically different results. One shows little effect; the other, a large one. The treatments agree on some thermal-zone water supplies to the Jemez River but not on the expected changes in these flows. The primary areas of disagreement appear to be the total volume of water in the reservoir and the movement of this water to the point of withdrawal. The author (a nonhydrologist) has compared these reports but leaves final judgment of the accuracy of either evaluation for some erudite hydrologists, as some experimental data and model development are needed.
\end{abstract}

\section{INTRODUCTION}

Two hydrological evaluations have been presented to describe the effect of a 50-megawatt hydrothermal power plant in the Valles Caldera of New Mexico on the water flow to surrounding lands. One evaluation, prepared by Water Resources Associates (WRA) of Arizona and reported in DOE/EIS-0049 (January 1980), ${ }^{2}$ shows that such a plant would cause a small $(\sim 1 \%)$ reduction in total Jemez River water flow over the plant's 30-yr pumping life. The other evaluation, prepared by W. P. Balleau (March 1980) ${ }^{3}$ for the Department of the Interior/Bureau of Indian Affairs (DOI/BIA), shows that such a plant would cause nearly complete depletion (75\%) of the Jemez water flow coming from thermal supplies. (Note the difference in comparisons: total vs thermal. The depletion rates for thermal supplies are graphically depicted for the two studies in Fig. 1.) The question is "Which (if either) evaluation is correct?" In this analysis, I have tried to discuss, from a nonhydrologist's point of view, the areas of agreement and discord.*

The important hydrological areas for the hydrothermal operation seem to be water supply, water

- This report is part of a DOE contract to Los Alamos National Laboratory to determine the environmental effects of hydrothermal energy and to determine areas needing attention. The original work was performed in 1980, and the last major revision of this report was made in 1984. depletion, and the environmental effect caused by any water loss. These are depicted in Fig. 2. Each area will be treated in a separate section. Briefly, however, general agreement is found between the two evaluations with regard to the amount of thermal waters being supplied to the Jemez River. Poor agreement occurs with regard to the influence of a hydrothermal operation on these thermal waters and hence its environmental effect. The

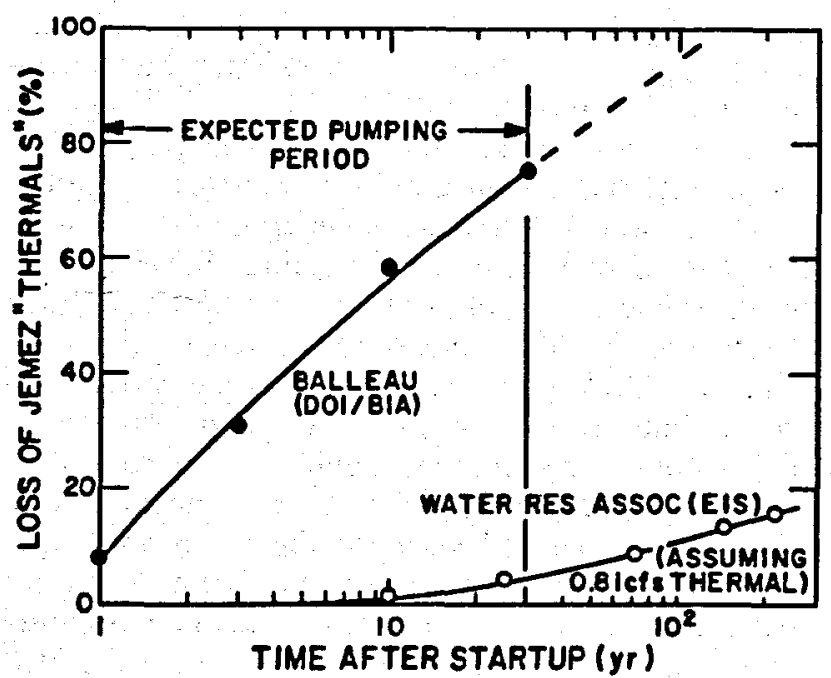

Fig. 1. Some predicted losses of thermal waters to the Jemez River. 


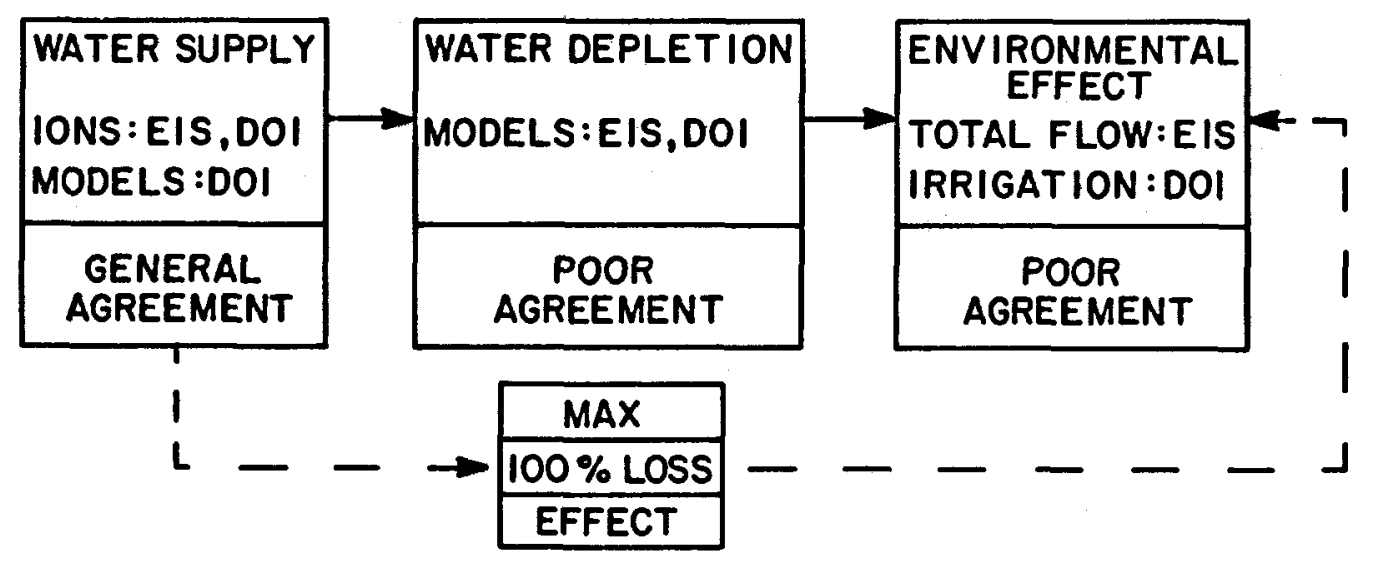

Fig. 2. Areas of debate in water impact modeling.

upper limit, of course, will be defined by $100 \%$ loss of the thermal water supply - a matter not clearly expressed in the two evaluations.

\section{THERMAL WATER SUPPLIES}

The classification of thermal waters associated with the proposed hydrothermal operation is a particularly difficult one. Underground waters flowing into the above-ground system can be thermally hot or cold and either mineralized or not. ${ }^{4-6}$ Even after classifying the many springs, fumaroles, etc., the assignment of each to a specific underground water subsystem would be very tenuous at best, considering the extreme complexity of the encompassing geological system. ${ }^{7-11}$ Because the aquifer proposed to be used in the hydrothermal operation is highly mineralized, ${ }^{2}$ it is reasonable (especially considering the many other uncertainties) to attribute, as the upper limit, all of the surface water mineralization as directly input from this aquifer.

The principal, observable, thermal activity in the Jemez Mountains is in the Soda Dam-Jemez Springs area (see Fig. 3). WRA ${ }^{1}$ chose to determine the supply at San Diego Canyon below Jemez Springs. Balleau ${ }^{3}$ chose to determine the supply from sources between Otowi Bridge and Bernalillo, including the Jemez River system. The WRA approach emphasizes the surface discharge route from the proposed site and includes the major hot springs in the region. It also recognizes published geological appraisals that indicate little movement of ground water to the north and east. ${ }^{1}$ Balleau's approach emphasizes the regional hydrological system, which follows water flow contours outward in all directions. ${ }^{3}$ This approach is supported by the premise that "the main aquifer of the Los Alamos area," which is "an extremely important discharge area of the Valles Caldera aquifer, discharges into the Rio
Grande."2 Interestingly, however, it has never been proved that water flows eastward from the Valles Caldera into the subsurface of the Pajarito Plateau. Of the two aquifers beneath the Pajarito Plateau, ${ }^{12}$ the "confined" aquifer has an isotopic signature that indicates recharge from the Sangre de Cristo Range eastward across the Rio Grande River Valley. ${ }^{13}$ The recharge for the "unconfined" aquifer is uncertain. A demonstration (which is lacking) of mineralized springs or seeps in the areas outside those included by WRA would give additional credence to the regional approach.

Chemical ions were used by both studies to determine the supply of thermal reservoir waters to the surrounding ground waters. Usable ions must be free of chemical interaction with the transporting water and its geological trough. Very soluble ions such as chloride could be leached from the trough media. Of course, most soluble ions would have been removed many years (millenia) before now if they occurred in soluble minerals. Very soluble ions could also be washed into the stream by rain. In the case of large rivers like the Rio Grande, intentional or, more likely, inadvertent inputs might come from man. Either input would give a higher than real answer. Such may be the Balleau case. Removal of ionic content by chemical or physical means would give an underestimation of the answer. Such may be the WRA case.

Using arsenic ion as a tracer, WRA determined that $0.365 \mathrm{cfs}$ of thermal waters is being loaded into the Jemez River down to position 5 (see Fig. 3). The Environmental Impact Statement (EIS) ${ }^{2}$ reports that this value can be $24 \%$ higher if other ions are used. Using numerous ionic species (chloride, bromide, lithium, boron, and sodium, but not fluoride, potassium, or arsenic!), Balleau determined that $0.81 \mathrm{cfs}$ ( $584 \mathrm{acre} \mathrm{ft} / \mathrm{yr}$ ) of thermal waters was being added down to position 5 and, within error, with no flow $(0.0 \mathrm{cfs})$ between there and San Ysidro (position 7$)$. I 


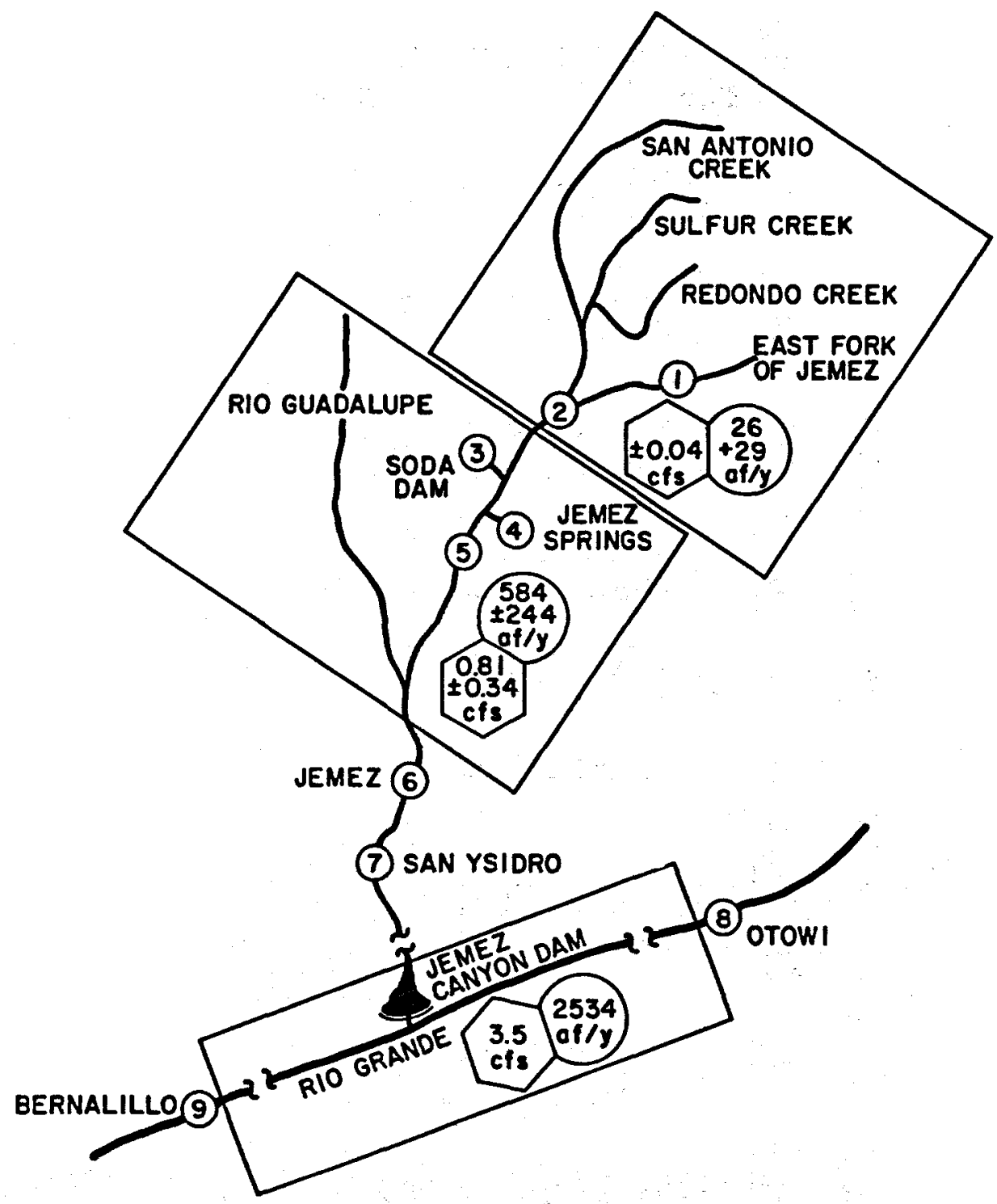

Fig. 3. Thermal water supplies along the Jemez River.

have reworked Balleau's data in Table $I$, combining positions 1 with 2 and 6 with 7 to reduce noise. [Note the large sigmas even after throwing out the extremes (arsenic and fluoride). Arsenic appears to give a somewhat lower (42\%) flow than the average. The chloride data and the average data are almost identical. In the future, however, supplies should be based on several ionic species.] The two evaluations seem to be in general accord about the hydrothermal supply down to San Ysidro.

Balleau further determined, by ion tracers, the hydrothermal supply from Otowi Bridge to Bernalillo to be $3.56 \mathrm{cfs}$ ( $2580 \mathrm{acre}-\mathrm{ft} / \mathrm{yr})$. My recalculation of these data shows $3.5 \mathrm{cfs}$. Of this, only $24 \%$ is contributed through the Jemez River down to San Ysidro. Balleau reports $4.1 \mathrm{cfs}$ out of the Jemez Canyon, based on one ion and one time event. Similarly, he reports $0.48 \mathrm{cfs}$ in the Rio Grande at Abiquiu and $1.39 \mathrm{cfs}$ at Otowi Bridge. These are depicted in Fig. 4. His numerical values do not yield a closed system. He explains the discrepancy between the inflow from the Jemez Canyon Dam $(5.0 \mathrm{cfs})$ and the Bernalillo outflow less the Otowi Bridge inflow ( $3.5 \mathrm{cfs}$ ) as possibly resulting "from Rio Grande seepage through reaches of the river where water is lost to groundwater recharge." Presumably he thinks salt water has a much greater propensity to seep than fresh water. I find his treatment a little hard to believe and suggest an alternative below. 
TABLE I

HYDROTHERMAL SUPPLY TO THE JEMEZ RIVER DOWN TO SAN YSIDRO^

\begin{tabular}{|c|c|c|c|c|c|c|c|c|c|c|c|c|c|}
\hline Element & $\mathrm{C}_{6}+\mathrm{C}_{7}$ & $\mathrm{C}_{1}+\mathrm{C}_{2}$ & $C_{3}$ & $\mathrm{C}_{4}$ & $\mathbf{C}_{\mathbf{j}}$ & $\left(\mathbf{Q}_{6}+Q_{7}\right) / 2$ & $\underline{\mathbf{Q}_{2}}$ & $\mathbf{Q}_{3}$ & $\mathbf{Q}_{4}$ & cfs & acre-ft/yr & cfs & acre-ft/yt \\
\hline As & 0.048 & 0.003 & 1.3 & 0.66 & 3.7 & 27 & 15 & 0.89 & 0.45 & -0.055 & -40 & 0.34 & 245 \\
\hline B & 0.8 & 0.02 & 13 & 7.4 & 23 & 27 & 15 & 0.89 & 0.45 & 0.278 & 202 & 0.926 & 670 \\
\hline $\mathrm{Cl}$ & 95 & 4.4 & 1550 & 920 & 3061 & 27 & 15 & 0.89 & 0.45 & 0.23 & 167 & 0.816 & 592 \\
\hline $\mathbf{F}$ & 1.1 & 0.6 & 3.6 & 4.8 & 6 & 27 & 15 & 0.89 & 0.45 & 2.56 & 1850 & 3.45 & 2500 \\
\hline $\mathbf{K}$ & 5.4 & 2.0 & 185 & 82 & 370 & 27 & 15 & 0.89 & 0.45 & -0.23 & -168 & 0.31 & 227 \\
\hline $\mathbf{L i}$ & 0.83 & 0.015 & 7.5 & 8.7 & 30 & 27 & 15 & 0.89 & 0.45 & 0.39 & 280 & 0.74 & 536 \\
\hline $\mathrm{Na}$ & 90 & 17 & 1030 & 640 & 1749 & 27 & 15 & 0.89 & 0.45 & 0.55 & 402 & 1.24 & 901 \\
\hline Average $^{b}$ & & & & & & & & & & 0.24 & 177 & 0.81 & 584 \\
\hline Sigma & & & & & & & & & & 0.29 & 212 & 0.34 & 244 \\
\hline
\end{tabular}

Data from DOI/Balleau, Table I.

Data for As and $F$ not included in average. 


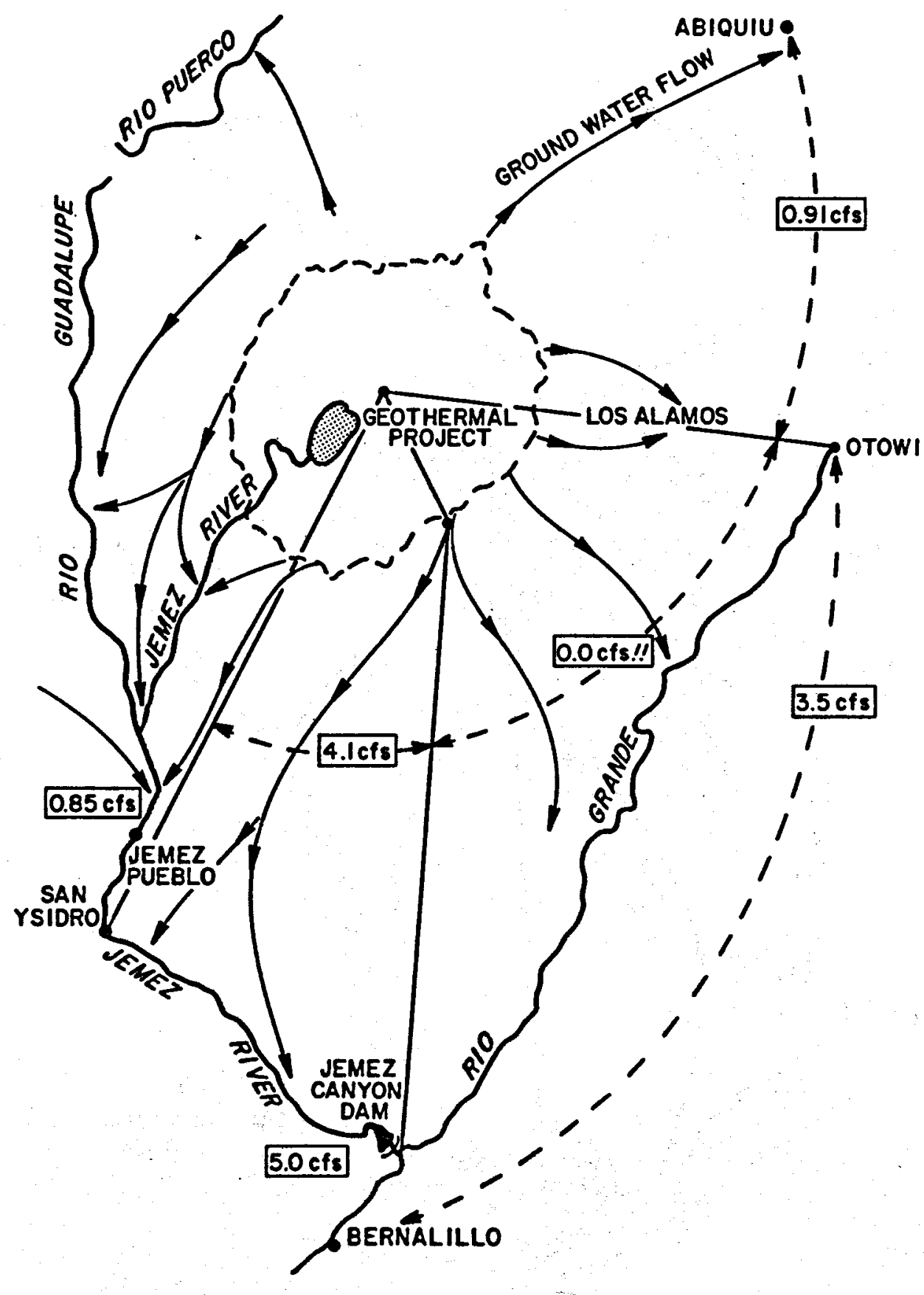

Fig. 4. Thermal supplies according to Balleau. ${ }^{3}$

Sectional thermal supplies can be roughly estimated by using water flow patterns and one sectional thermal supply value. This treatment is shown in Fig. 5 using the Jemez River thermal supply down to San Ysidro as the base. Total Jemez River thermal flow from its tributaries is estimated at $1.14 \mathrm{cfs}$, from which the total Valles Caldera thermal flow becomes $2.37 \mathrm{cfs}$. These estimates are compared with those from Balleau in
Table II. The main conflict comes in the Jemez RiverJemez Canyon Dam sector where Balleau reports $4.1 \mathrm{cfs}$ thermal flow vs $0.29 \mathrm{cfs}$ by the sector method. Balleau's value seems incredibly high $(65 \%$ of his total thermal flow) and comes from only $12 \%$ of the Valles Caldera through a sector with almost no surface water flow! I would guess that Balleau's high flow value comes from using ion values measured below a dam behind which 


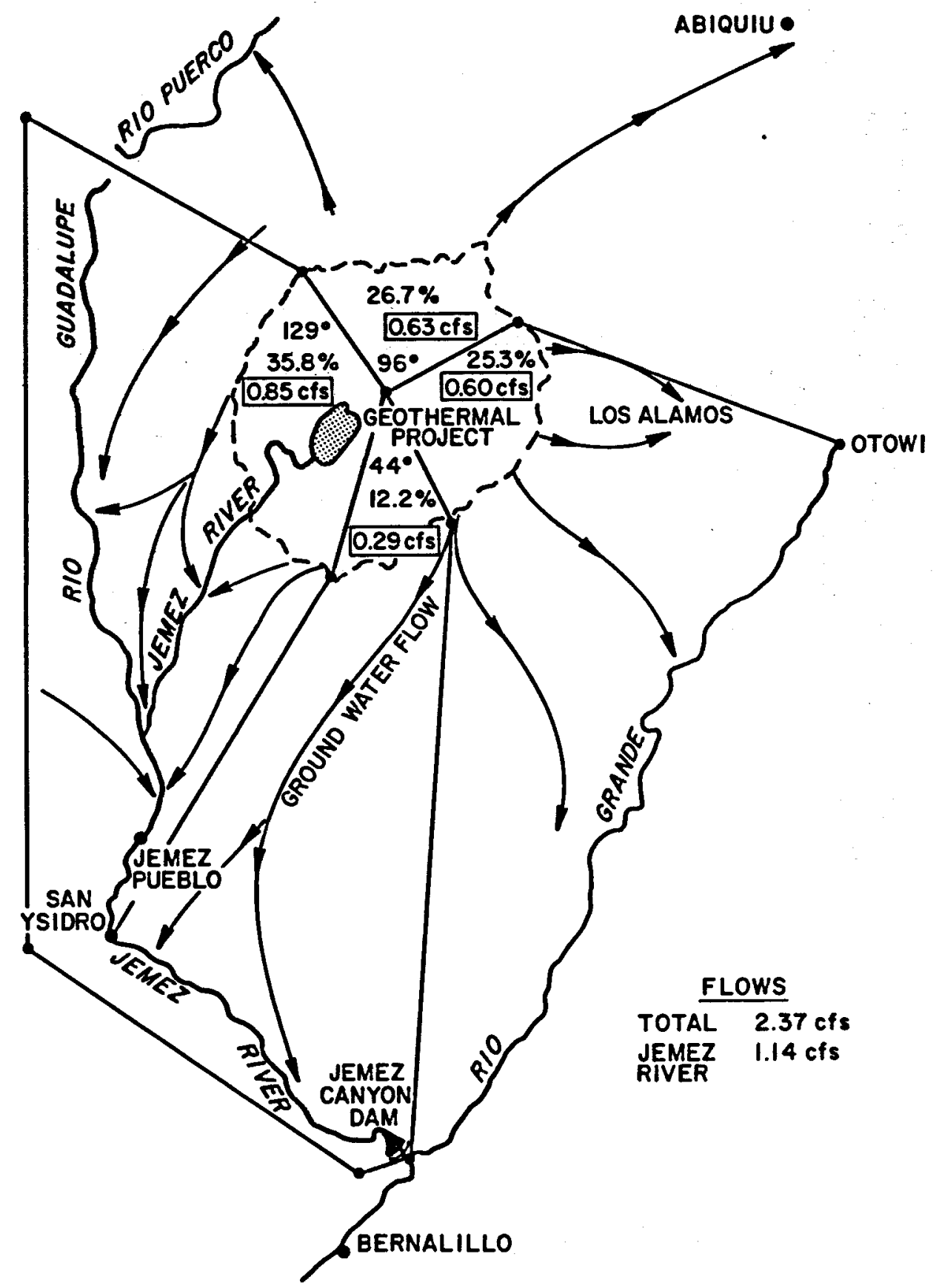

Fig. 5. Thermal supplies according to the sector method and based on the San Ysidro thermal flow. 
TABLE II

\section{BACA REGION THERMAL WATER SUPPLIES}

\begin{tabular}{|c|c|c|c|}
\hline \multirow[b]{2}{*}{ River } & \multirow[b]{2}{*}{ Sector } & \multicolumn{2}{|c|}{ Flow Rates (cfs) } \\
\hline & & $\begin{array}{l}\text { Balleau } \\
\text { (Fig. 4.) }\end{array}$ & $\begin{array}{l}\text { Sectional } \\
\text { (Fig. 5) }\end{array}$ \\
\hline Jemez & $\begin{array}{l}\text { San Ysidro } \\
\text { Jemez Canyon Dam }\end{array}$ & $\begin{array}{l}0.85 \\
4.1^{2}\end{array}$ & $\begin{array}{l}0.85 \\
0.29\end{array}$ \\
\hline Rio Grande & $\begin{array}{l}\text { Otowi } \\
\text { Jemez Canyon Dam }\end{array}$ & $\begin{array}{l}1.39 \\
0.0(?)\end{array}$ & $\begin{array}{l}0.63 \\
0.60\end{array}$ \\
\hline Rio Grande & $\begin{array}{l}\text { Sum } \\
\text { Sum minus Otowi } \\
\text { Bernalillo }\end{array}$ & $\begin{array}{l}6.34 \\
4.95 \\
3.5^{b}\end{array}$ & $\begin{array}{l}2.37 \\
1.74 \\
3.5^{b}\end{array}$ \\
\hline
\end{tabular}

Below Jemez Canyon Dam.

bHigh value believed by the current author to be caused, in part, by evaporation at the Jemez Canyon Dam.

salts are greatly concentrated by evaporation of water.* The concentration process could be the cause of some of the difference between the Rio Grande sum minus the Otowi value (1.74 cfs) and the Rio Grande/Bernalillo value ( $3.5 \mathrm{cfs})$; data for the dam release and Rio Grande flow are from different years. Other thermal supplies could be added directly to the Rio Grande through subterranean flow. This would eliminate the need for the fresh water/salt water seepage difference proposed by Balleau.

In summary, reasonable agreement is encountered in thermal flows into the Jemez River down to San Ysidro. The WRA/EIS treatment neglects flows elsewhere. Balleau considers the total picture but concentrates $65 \%$ of the total flow in the Jemez Canyon Dam area. Confirmation that this is a real thermal flow effect and not an evaporation phenomenon should be determined by comprehensive seasonal water sampling. Using a section-flow scheme, I calculated surface-water-related thermal flows to total $2.37 \mathrm{cfs}$ for the entire Valles Caldera and $1.14 \mathrm{cfs}$ down through the Jemez valley. If the high measured value from Otowi Bridge to Bernalillo is caused largely by subterranean thermal flows, the total thermal flow from the entire caldera might be about $\mathbf{S} \mathrm{cfs}$. Subterranean flow is not likely to alter the quantity of thermal flow down the Jemez River, however. Thermal flow through the Jemez River valley is likely to be $1.14 \mathrm{cfs}$, which is greater than the

\footnotetext{
During the time considered by Balleau and WRA, the Jemez Canyon Dam was a flood control dam with a small pool from 17 to $66 \%$ (mostly <50\%) of the year (see the Appendix). Evaporation from a pool of water will concentrate the salts, but the large observed concentrating effect is likely to come from evaporation over the long (>11 miles), broad $>1 / 2$ mile), flat basin (see the Appendix) through which the Jemez River flows to reach the dam. The small river has been observed by Corps of Engineers personnel to meander from side to side over this flat region.
}

0.365 cfs suggested by WRA and reported in the EIS but less than the $3.5 \mathrm{cfs}$ to $5 \mathrm{cfs}$ that Balleau proposes.

\section{THERMAL WATER SUPPLY DEPLETION}

If the thermal water supplies are considered to be somewhat agreed upon (only a factor of 10 difference in flow), then the depletion of these supplies must be considered to be poorly agreed upon: a factor of 200 difference in time to produce a $20 \%$ reduction in water supply. Both WRA and Balleau use models. The WRA account of its model is very sketchy, and no derivation is given. A transmissivity of $366 \mathrm{ft}^{2} /$ day is used, but no storage coefficient seems to be used. Balleau uses a 1974 model by R. E. Glover of Colorado State University. ${ }^{3}$ He uses a transmissivity of $146 \mathrm{ft}^{2}$ /day and a storage coefficient of 0.003 , which $I$ interpret as 3 cf of water per 1000 of of land matter.* Presumably, both accounts assume some sort of "uniform" reservoir material. Rather than critique their models as such, I have chosen to present several simple models of my own as a means of estimating their rationality. I am not a hydrologist and do not suggest that my models adequately represent the actual situation; rather I have used them as yardsticks.

\section{A. Simple Water Container Models}

Three simple water container models are shown in Fig. 6: a water tower, a funnel, and two independent zones. When water flow is rapid through the ground mass relative to the rate of fluid withdrawal at the pump site, the water tower would be a crude representation. It is probably unreasonable to think that a large water tank filled with permeable rock is a good model of the Jemez Mountains hydrological system with its rim and associated fault zones. Over a very large area one might expect tremendously large local variations to smooth out, however. This model and the others are offered only as means of applying a simplified approach to evaluating an extremely complex problem. If the pump rate exceeds the lateral water movement, a funnel would develop. At the extreme, the funnel would reach all the way down to the pumping point. The funnel is a very rough approximation of the parabola expected for steady radial flow to a well. ${ }^{15}$ In the case where downflow is negligible, as would occur if water were primarily moved through unconnected fault zones, a two-zone system must exist to permit pumping; recharge would presumably be through the ends of the production zone rather than from above.

*This is equivalent to spreading $357 \mathrm{gal}$. of water evenly on a football field and letting it permeate uniformly to a depth of $1 \mathrm{ft}$. Storage coefficient is defined ${ }^{14}$ as the volume of water released from storage in a vertical column of $1.0 \mathrm{ft}^{2}$ when the water table declines $1.0 \mathrm{ft}$. 


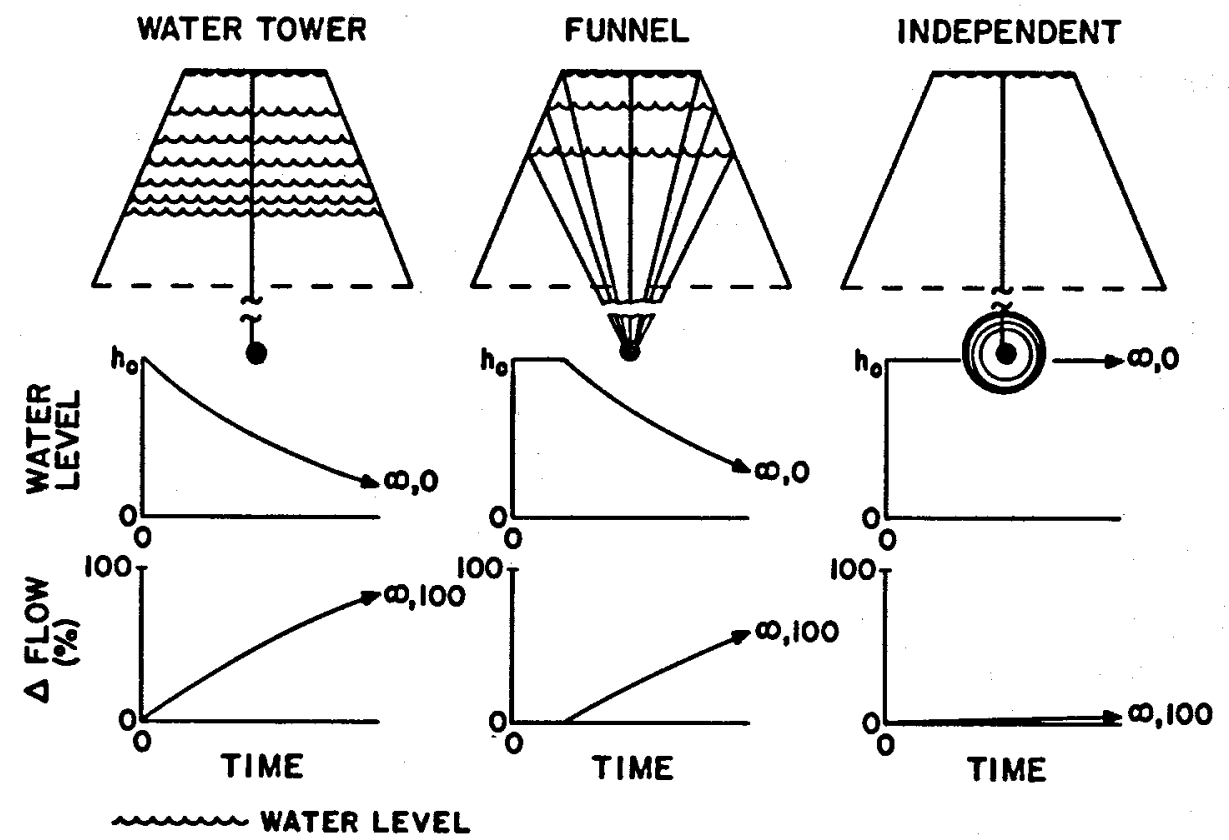

Fig. 6. Drawdown models.

Drawdown effects are quite different for the three simple models. In the water tower model, the effect of pumping would occur immediately and decrease with time until all the water was pumped out. In the funnel model, the effect of pumping would not be felt on the water level at the edges until the funnel edges reached the rim of the area. Close to the pumping point, the effect would be much greater than for the tower model! After this delay, the drawdown would be slower for the funnel model than for the water tower model if the pumping site is well below the bottom of the frustum, as at a comparable water level the funnel contains greater volume than does the water tower. In the independent zone model, the effect of pumping on water level is negligible.

The rate of drawdown (decrease in water level) will depend primarily on the pumping rate, the amount of water that can be pumped (storage), the physical dimensions of the reservoir, the flow of water (transmissivity) down to the pump site, and, locally, on the fracturing. The maximum drawdown rate for a uniform reservoir should occur in the water tower model. The ultimate drawdown level after pumping has stopped should also correspond to the level in the water tower model if no external recharge occurs and the pumping zone and water level are indeed connected.
1. Water Tower Model. Water levels at any given time in the water tower model are determined by assuming a water system shaped like the frustum of a cone with uniform storage throughout. Values for a "tower" $1120 \mathrm{ft}$ high with a top diameter of 4 miles and a bottom diameter of 20 miles are given in Fig. 7. The timedependent data are plotted in Fig. 8. Values for a "tower" $1120 \mathrm{ft}$ high with a top diameter of 15 miles and a bottom diameter of 45 miles are given in Fig. 9. The time-dependent data are plotted in Fig. 10. The latter system reflects the distance from the top rim of the Valles Caldera to the Jemez Pueblo. The pump rate in each case is $3.62 \mathrm{cfs}$ or $2620 \mathrm{acre}-\mathrm{ft} / \mathrm{yr}$. Note the significant effect that the water storage percentage has on the time to achieve a given reduction.

2. Funnel Model. Water levels at any given time in the funnel model are determined by assuming a water system shaped like that of the water tower model, with uniform storage throughout. A system $1120 \mathrm{ft}$ high with a pumping rate of $3.62 \mathrm{cfs}$ is used. If the pump site is at the bottom of the system, the values in Fig. 11 are obtained. The time-dependent data are plotted in Fig. 12. A potentially more realistic case is presented in Fig. 13 where the pump position is $6000 \mathrm{ft}$ below the top of the frustum. The time-dependent data for this example are plotted in Fig. 14. 


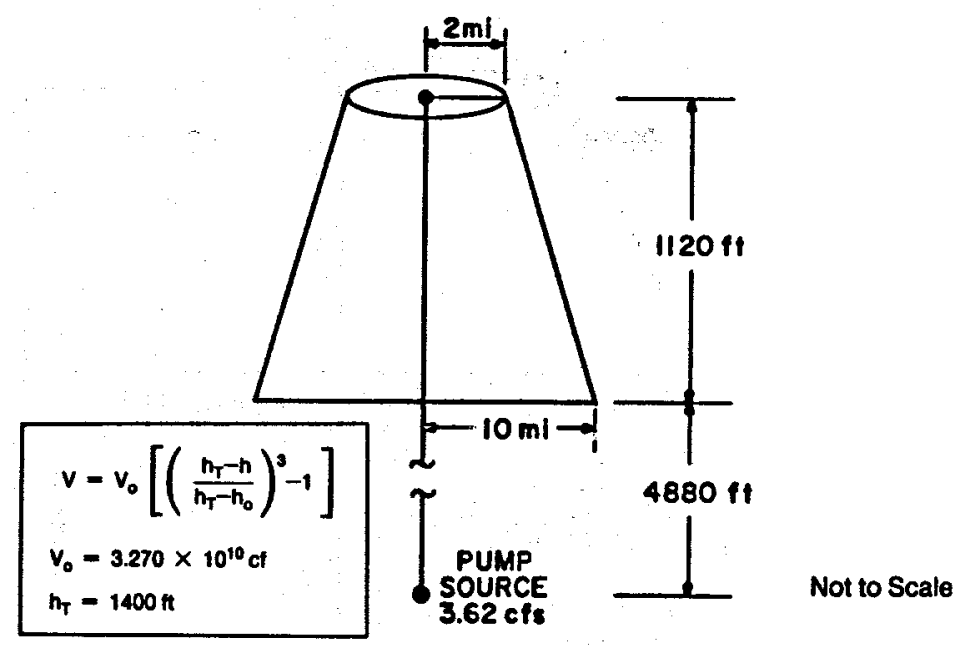

Time to Reach $\Delta h$ (years)

\begin{tabular}{|c|c|c|c|c|c|c|c|c|}
\hline $\mathbf{h}$ & $\Delta \mathbf{h}$ & $\% \Delta h$ & $v_{\text {cum }}(\mathrm{cl})$ & $100 \% \mathrm{H}_{2} \mathrm{O}$ & $10 \% \mathrm{H}_{2} \mathrm{O}$ & $1 \% \mathrm{H}_{2} \mathrm{O}$ & $0.3 \% \mathrm{H}_{2} \mathrm{O}$ & $0.1 \% \mathrm{H}_{2} \mathrm{O}$ \\
\hline 1120 & 0 & 0 & 0 & - & - & - & - & - \\
\hline 1110 & 10 & 0.89 & $3.63 \times 10^{9}$ & 31.0 & 3.1 & 0.31 & 0.10 & 0.03 \\
\hline 1020 & 100 & 8.9 & $4.90 \times 10^{10}$ & 429 & 42.9 & 4.3 & 1.3 & 0.43 \\
\hline 920 & 200 & 17.9 & $1.320 \times 10^{11}$ & 1156 & 116 & 11.6 & 3.5 & 1.2 \\
\hline 620 & 500 & 44.6 & $6.741 \times 10^{11}$ & 5909 & 591 & 59.1 & 17.7 & 5.9 \\
\hline 320 & 800 & 71.4 & $1.84 \times 10^{12}$ & 16140 & 1610 & 161 & 48 & 16 \\
\hline 120 & 1000 & 89.3 & $3.09 \times 10^{12}$ & 27060 & 2710 & 271 & 81 & 27 \\
\hline 0 & 1120 & 100 & $4.05 \times 10^{12}$ & 35490 & 3550 & 355 & 106 & 36 \\
\hline
\end{tabular}

Fig. 7. Water tower model (4-mile diam).

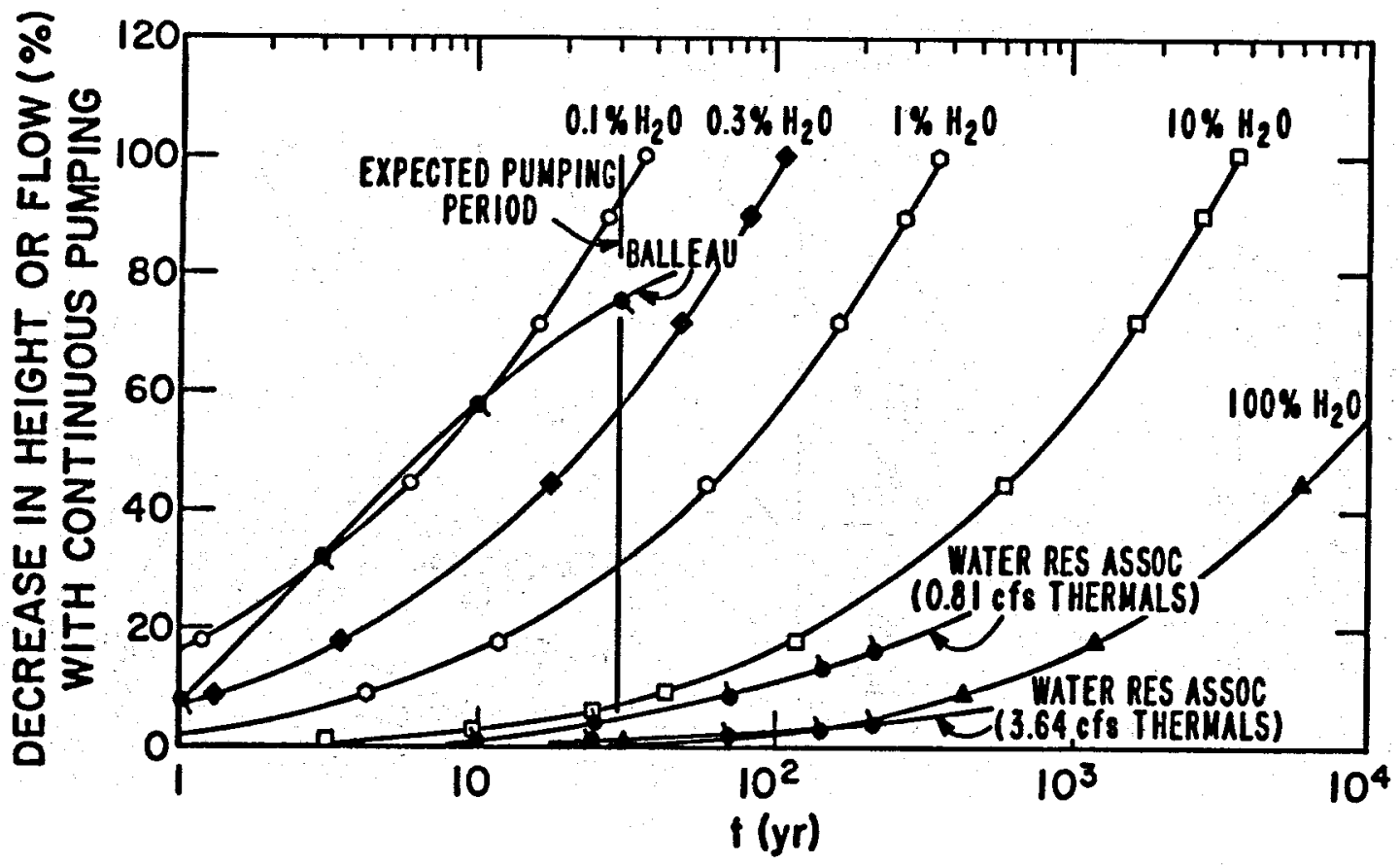

Fig. 8. Flow depletion for water tower model (4-mile diam). 


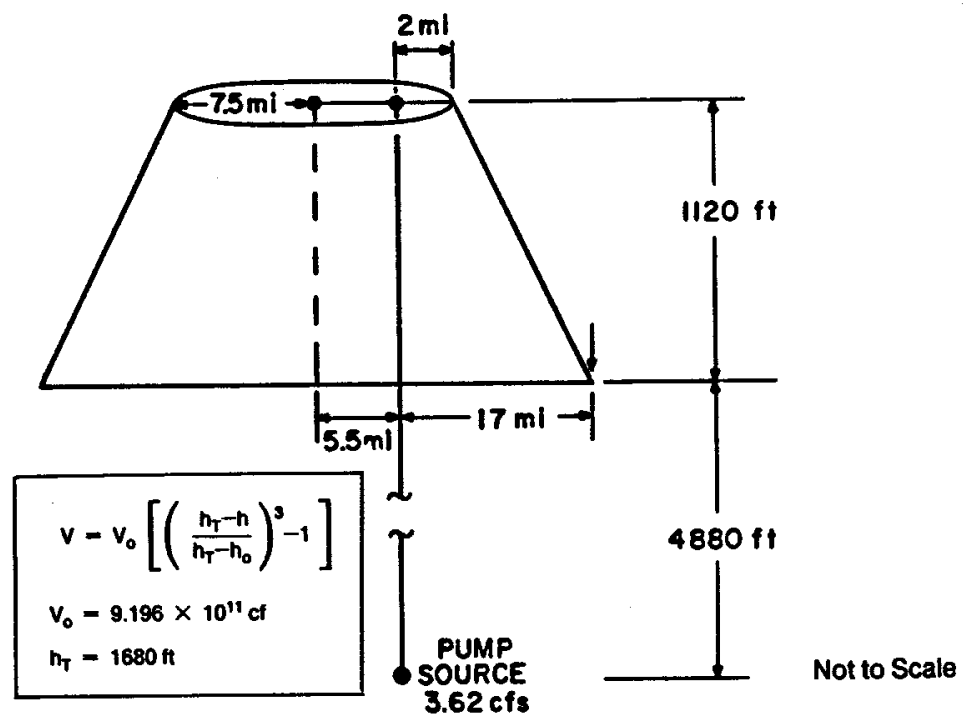

\begin{tabular}{|c|c|c|c|c|c|c|c|c|}
\hline \multirow[b]{2}{*}{ h } & \multirow[b]{2}{*}{$\Delta \mathbf{h}$} & \multirow[b]{2}{*}{$\% \Delta \mathrm{h}$} & \multirow[b]{2}{*}{$v_{\text {cum }}(c)$} & \multicolumn{5}{|c|}{ Time to Reach $\Delta$ h (years) } \\
\hline & & & & $100 \% \mathrm{H}_{2} \mathrm{O}$ & $10 \% \mathrm{H}_{2} \mathrm{O}$ & $1 \% \mathrm{H}_{2} \mathrm{O}$ & $0.3 \% \mathrm{H}_{2} \mathrm{O}$ & $0.1 \% \mathrm{H}_{2} \mathrm{O}$ \\
\hline 1120 & 0 & 0 & 0 & - & - & - & - & - \\
\hline 1110 & 10 & 0.89 & $5.02 \times 10^{10}$ & 439 & 43.9 & 4.39 & 1.32 & 0.44 \\
\hline 1020 & 100 & 8.9 & $5.86 \times 10^{11}$ & 5130 & 513 & 51.3 & 15.4 & 5.1 \\
\hline 920 & 200 & 17.9 & $1.379 \times 10^{12}$ & 12100 & 1210 & 121 & 36.2 & 12.1 \\
\hline 620 & 500 & 44.6 & $5.317 \times 10^{12}$ & 46500 & 4650 & 465 & 140 & 46.5 \\
\hline 320 & 800 & 71.4 & $1.225 \times 10^{13}$ & 107000 & 10700 & 1070 & 322 & 107 \\
\hline 120 & 1000 & 89.3 & $1.896 \times 10^{13}$ & 166000 & 16600 & 1660 & 498 & 166 \\
\hline 0 & 1120 & 100 & $2.39 \times 10^{13}$ & 209000 & 20900 & 2090 & 628 & 209 \\
\hline
\end{tabular}

Fig. 9. Water tower model (15-mile diam).

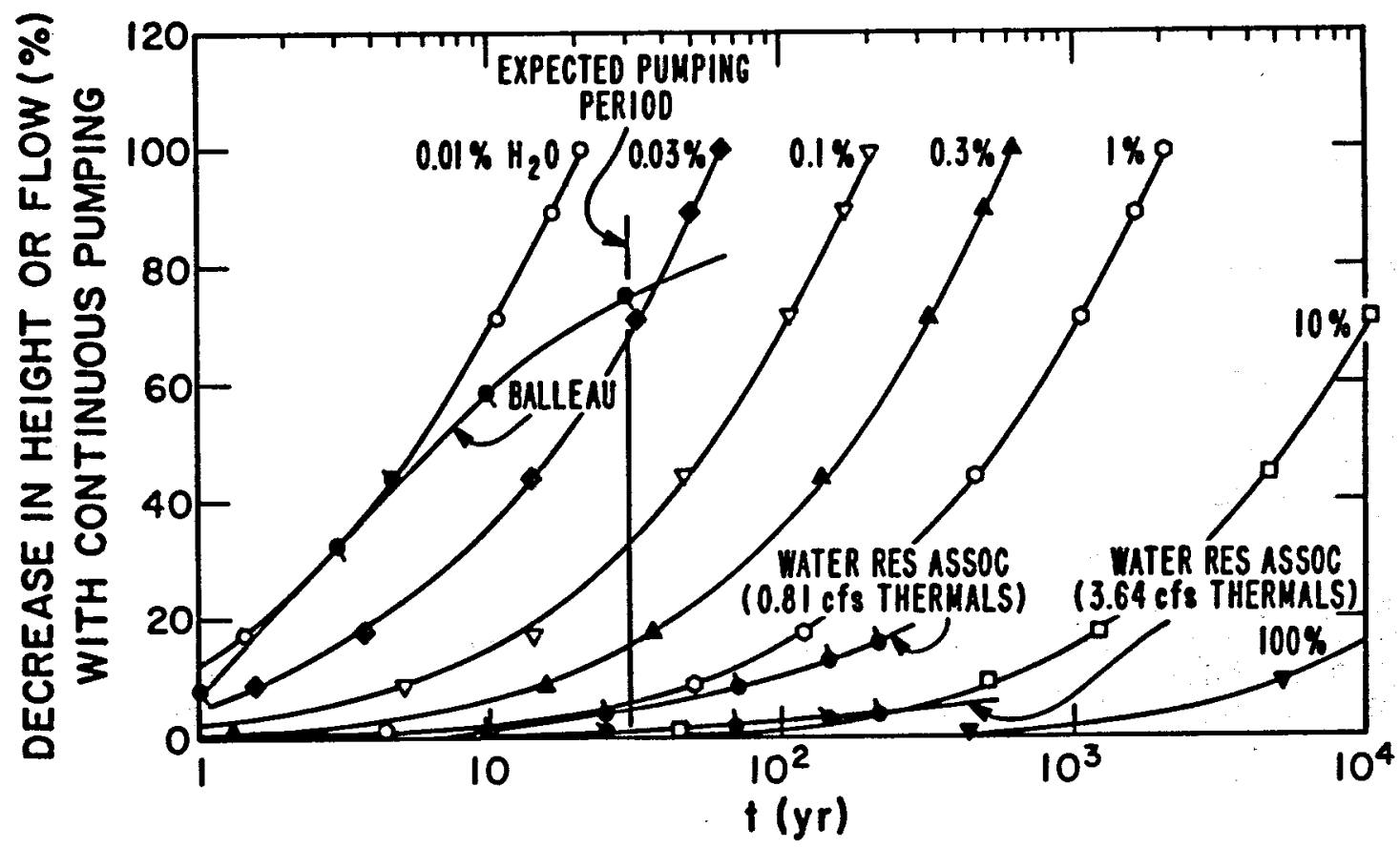

Fig. 10. Flow depletion for water tower model (15-mile diam). 

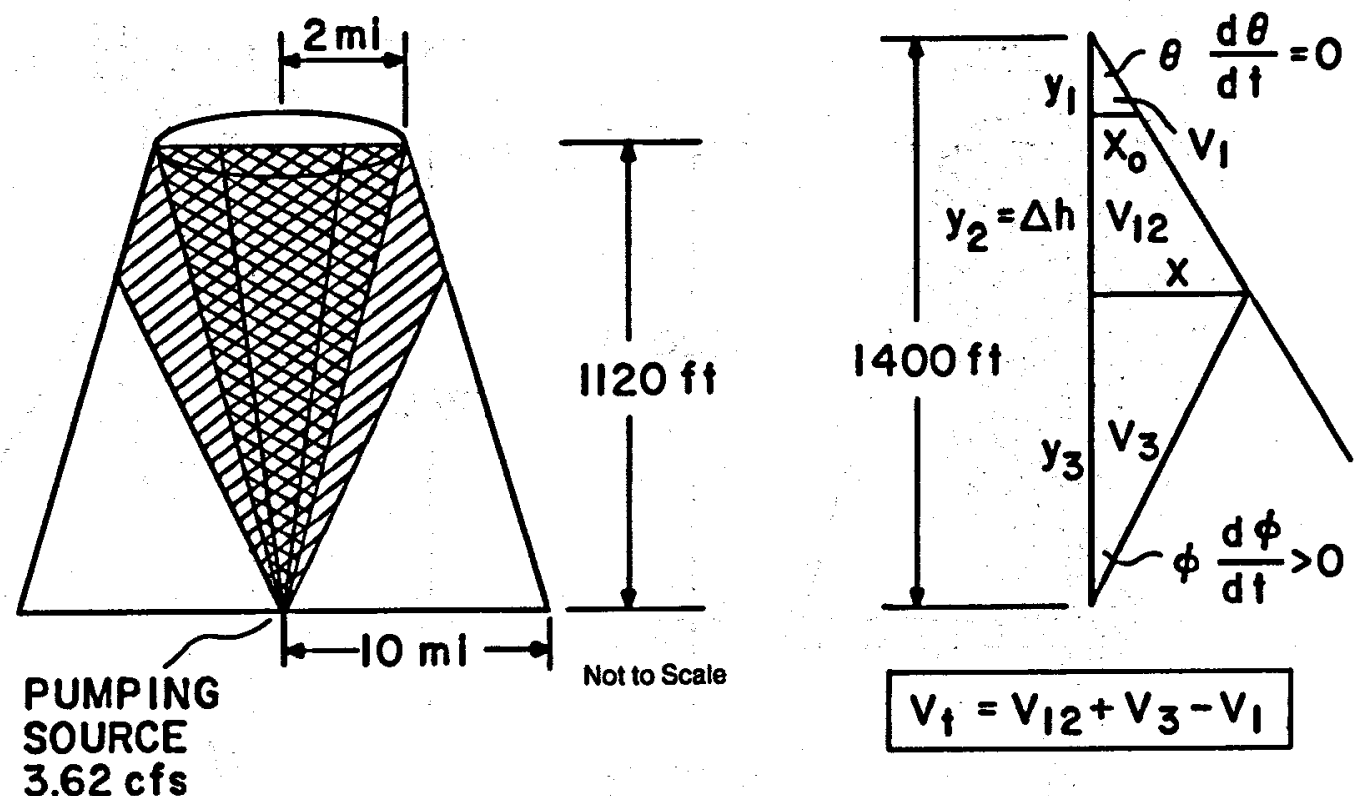

3.62 cfs

Time to Reach $\Delta$ h (years)

\begin{tabular}{|c|c|c|c|c|c|c|c|c|}
\hline b & $\Delta \mathbf{h}$ & $\% \Delta h$ & $v_{\text {cum }}(\mathrm{c})$ & $100 \% \mathrm{H}_{2} \mathrm{O}$ & $10 \% \mathrm{H}_{2} \mathrm{O}$ & $1 \% \mathrm{H}_{2} \mathrm{O}$ & $0.3 \% \mathrm{H}_{2} \mathrm{O}$ & $0.1 \% \mathrm{H}_{2} \mathrm{O}$ \\
\hline 1120 & 0 & 0 & $1.31 \times 10^{11}$ & 1148 & 115 & 11.5 & 3.4 & 1.1 \\
\hline 1110 & 10 & 0.89 & $1.43 \times 10^{11}$ & 1253 & 125 & 12.5 & 3.8 & 1.2 \\
\hline 1020 & 100 & 8.9 & $2.68 \times 10^{11}$ & 2348 & 235 & 23.5 & 7.0 & 2.4 \\
\hline 920 & 200 & 17.9 & $4.48 \times 10^{11}$ & 3924 & 392 & 39 & 11.8 & 3.9 \\
\hline 720 & 400 & 35.7 & $9.32 \times 10^{11}$ & 8164 & 816 & 82 & 24 & 8.2 \\
\hline 520 & 600 & 53.6 & $1.58 \times 10^{12}$ & 13840 & 1384 & 138 & 42 & 14 \\
\hline 320 & 800 & 71.4 & $2.40 \times 10^{12}$ & 21020 & 2102 & 210 & 63 & 21 \\
\hline 0 & 1120 & 100 & $4.05 \times 10^{12}$ & 35480 & 3548 & 355 & 106 & 36 \\
\hline
\end{tabular}

Fig. 11. Funnel model with shallow-well pumping point.

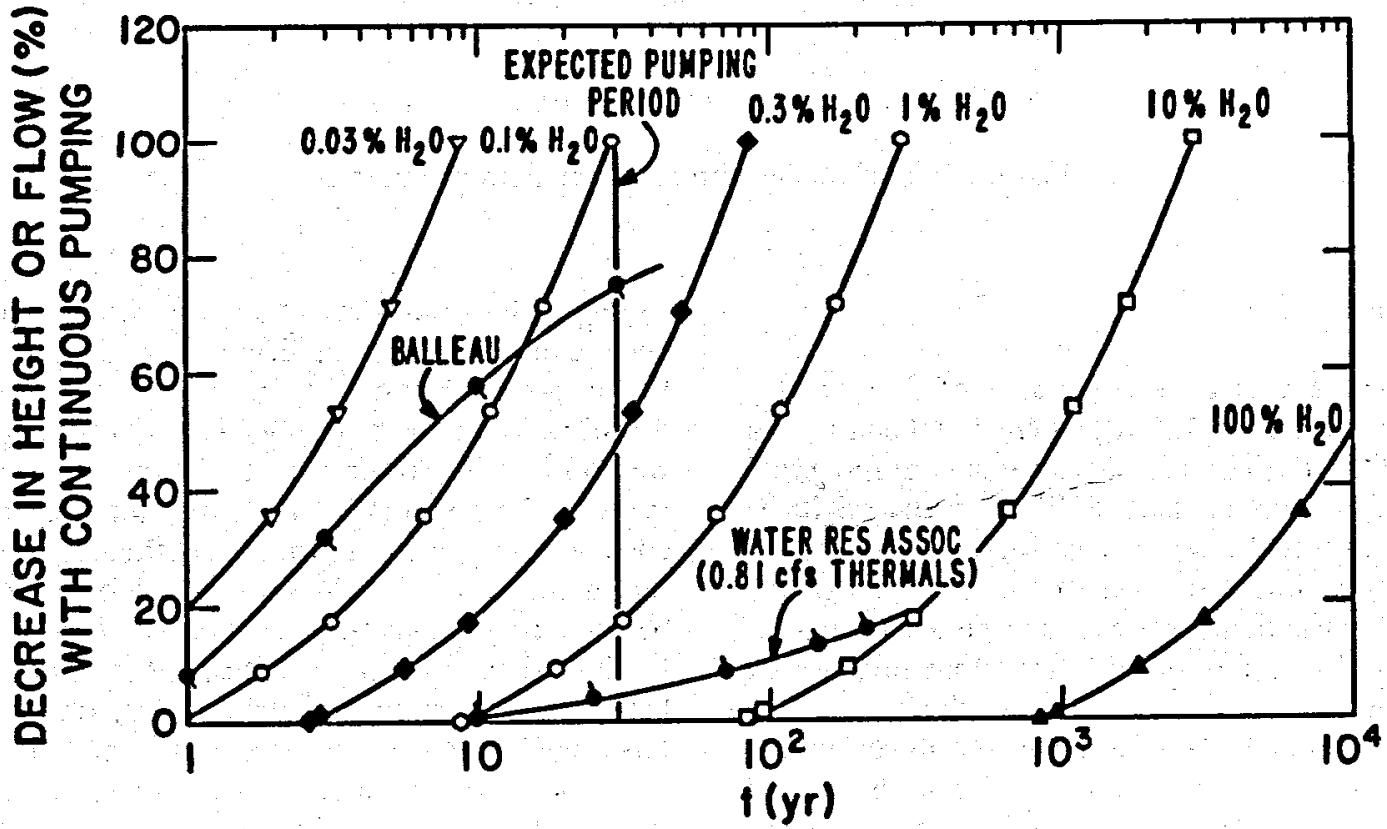

Fig. 12. Flow depletion for funnel model with shallow-well pumping point. 

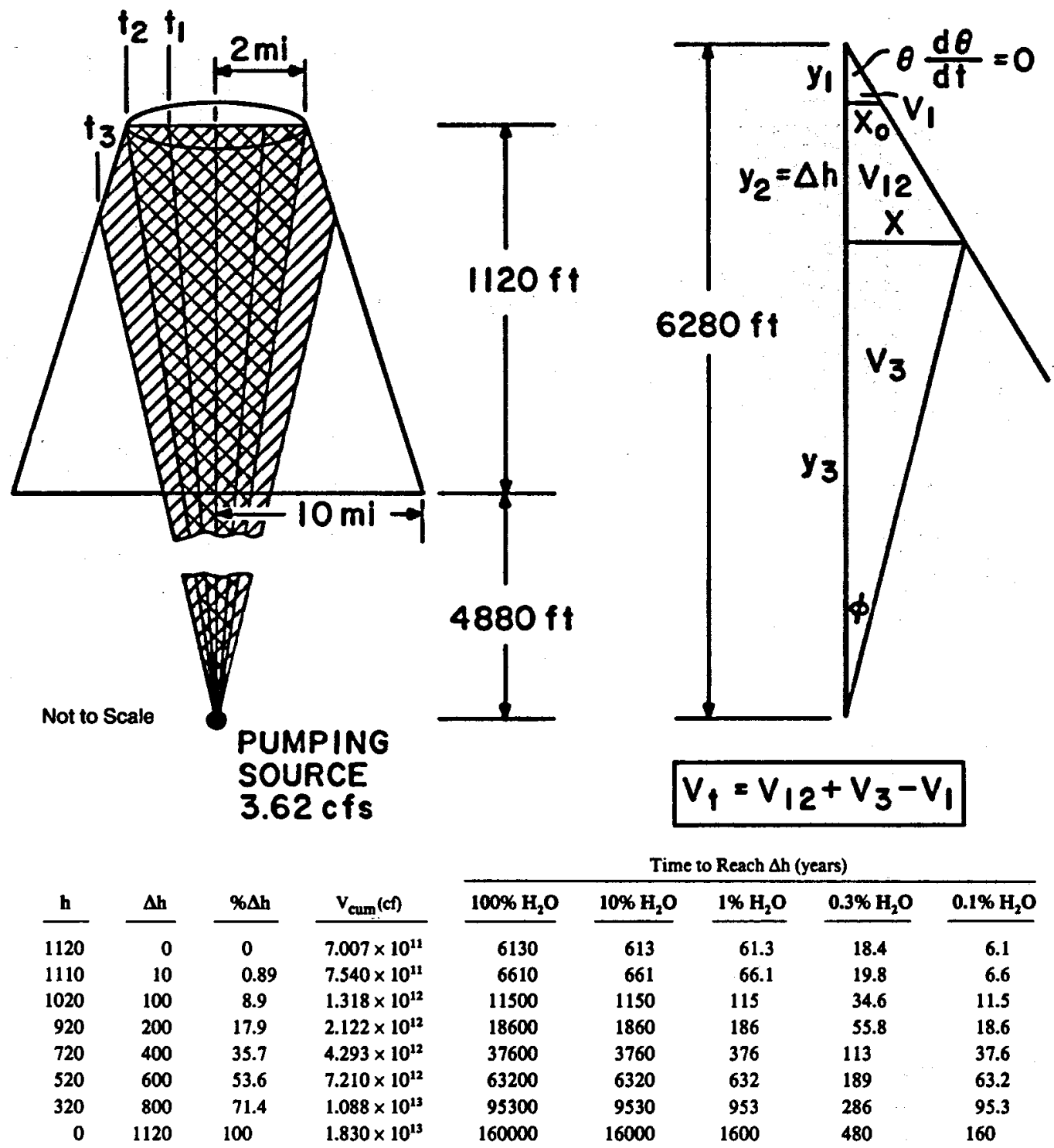

\begin{tabular}{|c|c|c|c|c|}
\hline \multicolumn{5}{|c|}{ Time to Reach $\Delta$ h (years) } \\
\hline $100 \% \mathrm{H}_{2} \mathrm{O}$ & $10 \% \mathrm{H}_{2} \mathrm{O}$ & $1 \% \mathrm{H}_{2} \mathrm{O}$ & $0.3 \% \mathrm{H}_{2} \mathrm{O}$ & $0.1 \% \mathrm{H}_{2} \mathrm{O}$ \\
\hline 6130 & 613 & 61.3 & 18.4 & 6.1 \\
\hline 6610 & 661 & 66.1 & 19.8 & 6.6 \\
\hline 11500 & 1150 & 115 & 34.6 & 11.5 \\
\hline 18600 & 1860 & 186 & 55.8 & 18.6 \\
\hline 37600 & 3760 & 376 & 113 & 37.6 \\
\hline 63200 & 6320 & 632 & 189 & 63.2 \\
\hline 95300 & 9530 & 953 & 286 & 95.3 \\
\hline 160000 & 16000 & 1600 & 480 & 160 \\
\hline
\end{tabular}

Fig. 13. Funnel model with deep-well pumping point.

\section{B. Discussion}

WRA used a transmissivity value of $366 \mathrm{ft}^{2}$ /day ( $4.7 \mathrm{cfs}$ with a head of $1120 \mathrm{ft}$ ), whereas Balleau used a value of $146 \mathrm{ft}^{2} /$ day $(1.9 \mathrm{cfs})$. Because the pumping rate is scheduled to be $3.62 \mathrm{cfs}$, the WRA results might be expected to mimic the water tower model, whereas the Balleau results should deviate in the direction of the funnel model and hence show smaller effects. Inspecting Figs. 8, 10,12, and 14, one finds that this is only partially true.

The WRA model mimics the water tower model reasonably well (Figs. 8 and 10) and not the funnel model (Figs. 12 and 14). For reservoirs of this size, the WRA model corresponds to the $10 \%$ to $100 \%$ water storage values ( $3.64 \mathrm{cfs}$ ), however, which leads me to believe that a storage coefficient is missing or is large or that a larger reservoir has been used. Using the WRA drawdown data to define a water tower model (Fig. 15), we find that the tower must be 28 miles in diameter at the top. This seems a little large for the area under consideration. With a storage coefficient of $0.3 \%$ and the smaller tower, the WRA model looks as if it might be predicting impact times that are too long.

The Balleau model does not appear to mimic or fall between either simple model (Figs. 8, 10, 12, and 14)! His model does have one point (at year 1 ) in common with the 4-mile-diameter water tower model at his expressed storage coefficient (Fig. 8). All his other values are well above those of a water tower model of 


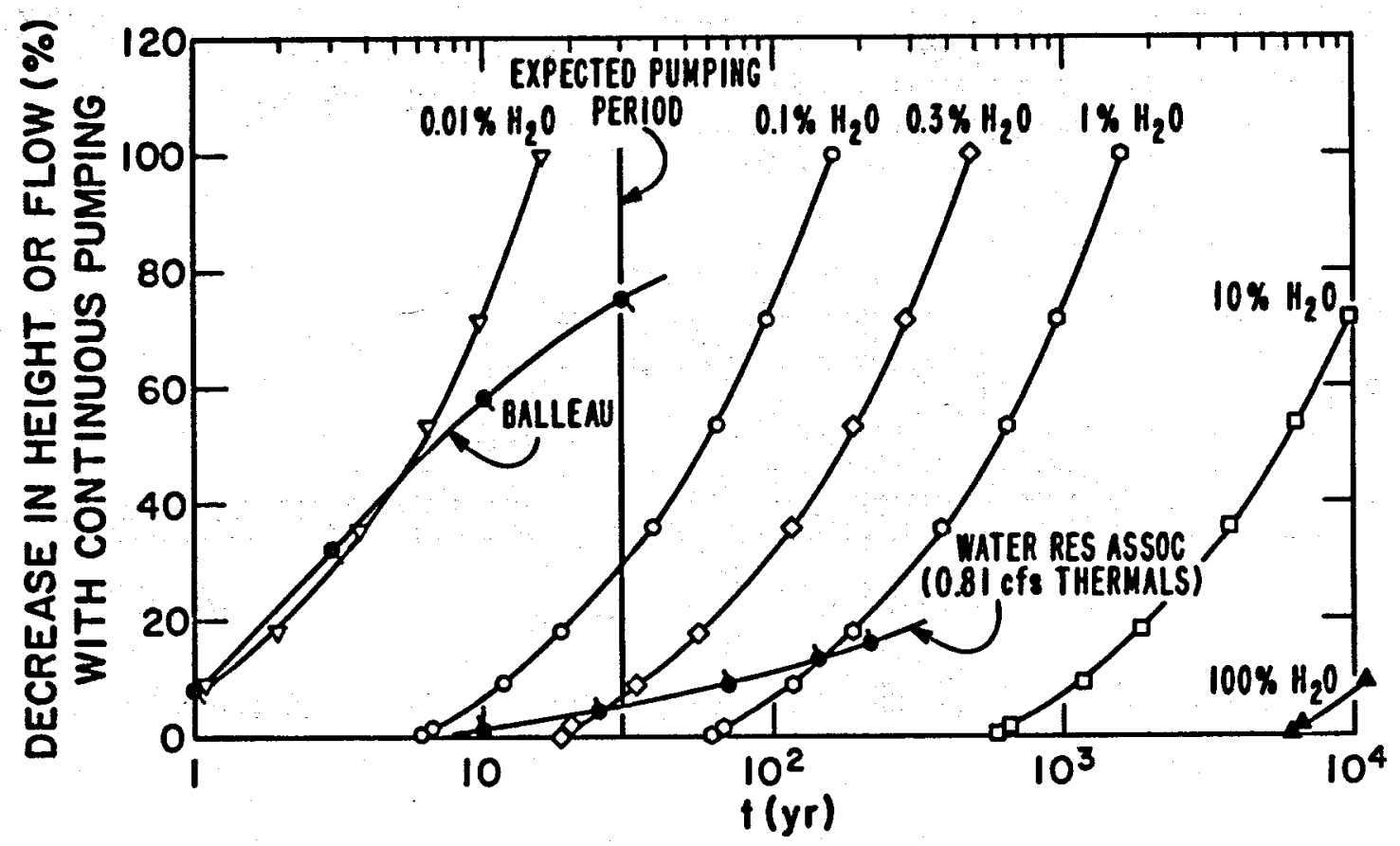

Fig. 14. Flow depletion for funnel model with deep-well pumping point.

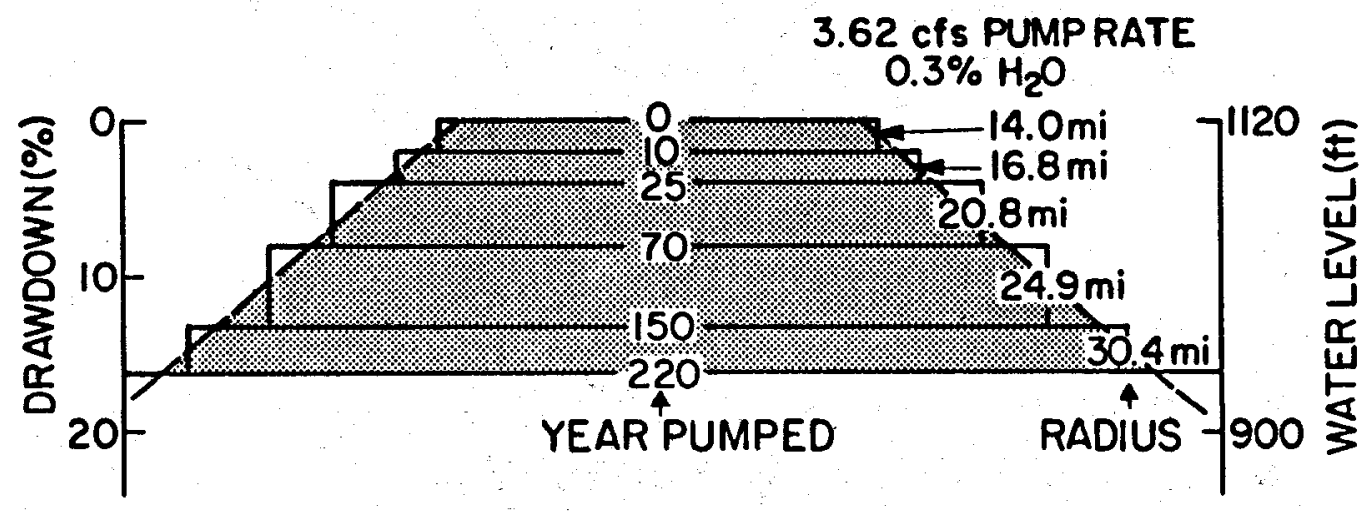

Fig. 15. A water tower constructed from the WRA drawdown data ${ }^{1}$ using a $3.62 \mathrm{cfs}$ pumping rate and a $0.3 \%$ water storage coefficient.

either size. The water tower shown in Fig. 16 is needed to fit Balleau's drawdown data. The slope outward at the bottom is expected, but the upper portion certainly does not correspond to the area under consideration. Turned over, the shaded area looks like the effect one should get from pumping a well. ${ }^{15}$ Indeed, if Balleau's data are plotted differently (Fig. 17), this behavior (drawdown contours) is clearly seen. Balleau's results represent the type of flow behavior the steam supplier should encounter at the well head. The tremendous drawdown rates that Balleau predicts arise from his choice of a small ( $\sim 2$ mi diam) column down through the pumping zone. This is a short-term effect, not a long-term one. Balleau's model, using his storage coefficient, looks as if it is predicting impact times that are too short.

The extreme discrepancy in drawdown impacts between WRA and Balleau thus appears to be a matter of looking at two different aspects of the same problem. Balleau seems to have confirmed the fact that the 


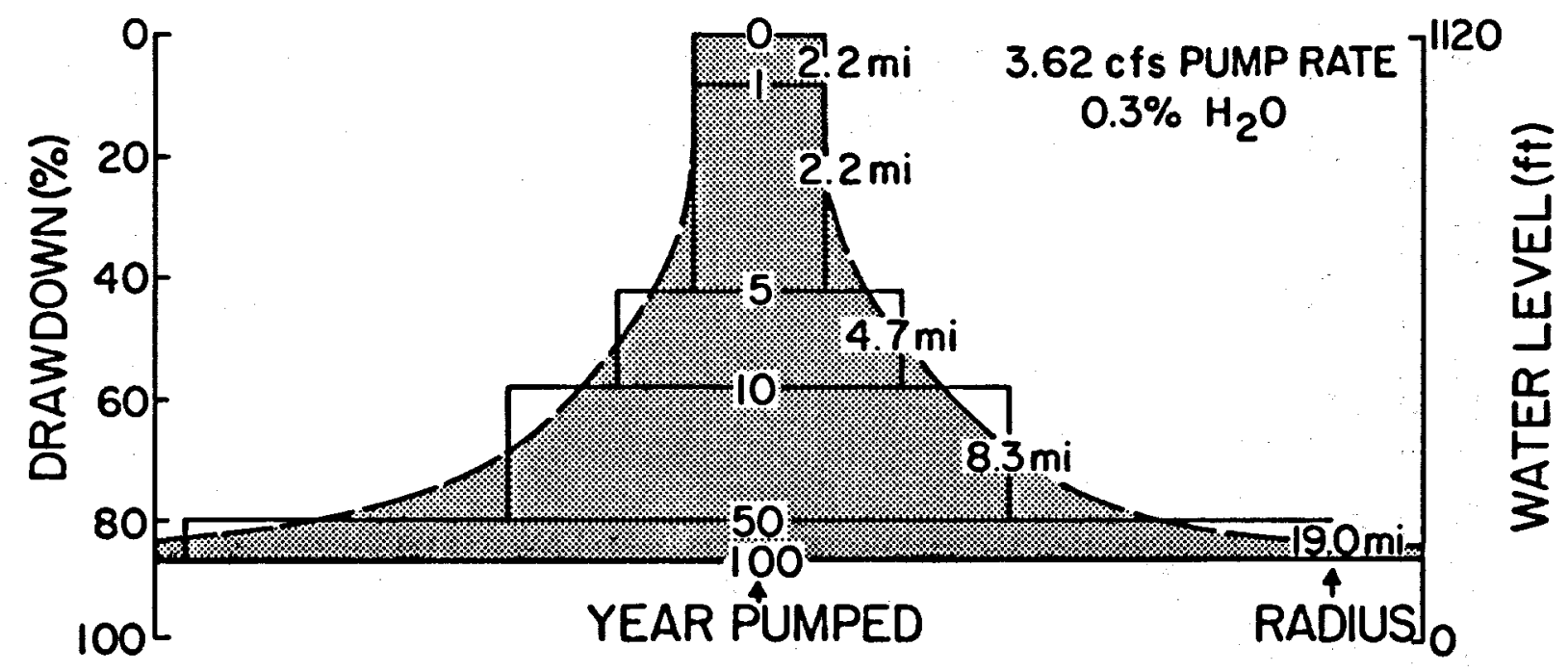

Fig. 16. A water tower constructed from Balleau's drawdown data ${ }^{3}$ using a $3.62 \mathrm{cfs}$ pumping rate and a $0.3 \%$ water storage coefficient.

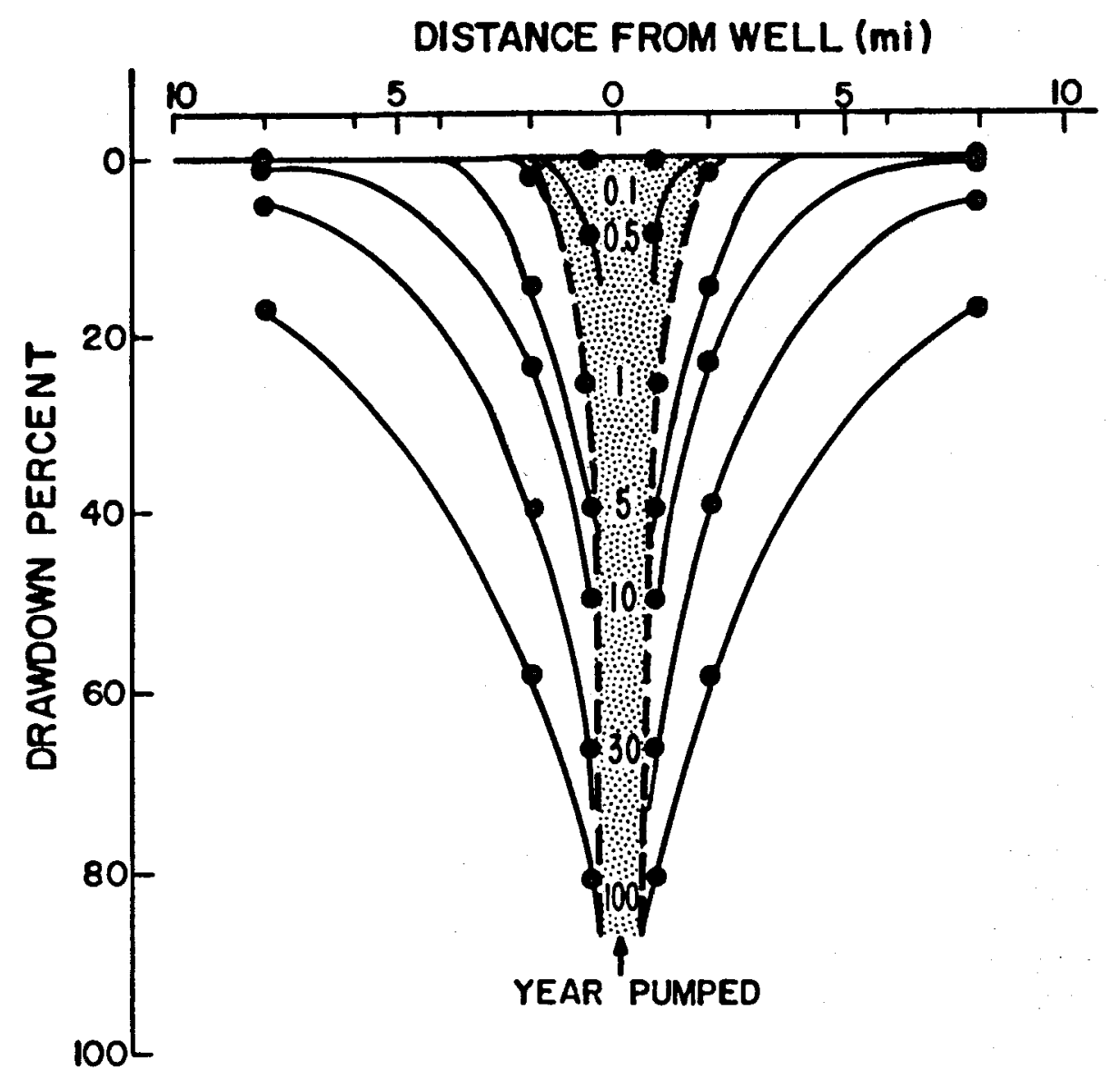

Fig. 17. Equi-time drawdown contours based on data by Balleau. ${ }^{3}$ The shaded area represents Balleau's predicted impact. 
geothermal well area will have a $30-y r$ life and that during this time drawdown near the well will be extreme. He does not consider the wide-range, long-term effect of backfilling this pumped zone. WRA does not consider the short-term effect but rather points out the long-term one. The extent of the WRA total reservoir may be exaggerated.

Both the WRA and Balleau data are plotted in Fig. 18 , along with the water tower model values for $0.3 \%$ water storage and diameters of 4 miles and 15 miles. The 4-mile data are included because the wells will be drilled close to one edge of the caldera; the 15-mile data are included because the total area is actually larger than 4 miles in diameter. The actual yearly effect, up to the end of the pumping period, will be increasingly less, depending on how much of a funnel is formed. When pumping ceases, the decrease should continue until the funnel is filled. Recharge from rain and snow will decrease this ultimate reduction in thermal flows, but at the expense of reducing the surface runoff. This might simply be a tradeoff to those getting water from the Valles Caldera.

\section{IRRIGATION ACREAGE LOST BY THERMAL SUPPLY DEPLETION}

Both the WRA and Balleau treatments of the impact of water losses are confined to the Jemez River valley.

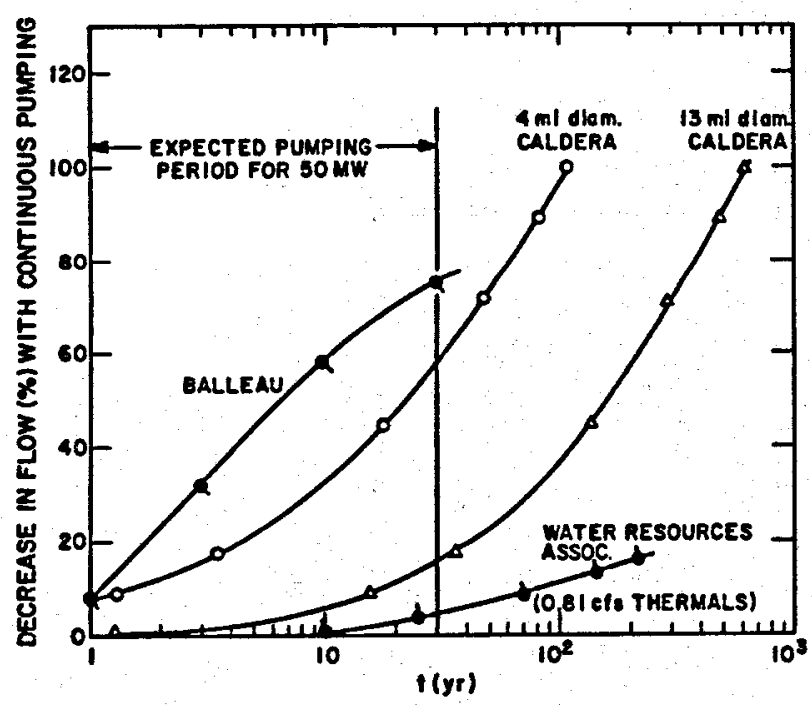

Fig. 18. Flow depletion predicted by several models.
(More extensive impacts are discussed at the end of this section.) The WRA method looks at the number of acrefeet of water lost per year and relates this to the number of acres of land needed to produce that much water from the average precipitation found in the Valles Caldera. This seems to be all right if the water were dammed, but the streams are free-flowing to the Jemez Canyon Dam. Balleau's treatment for the summer acreage irrigated above the dam seems more reasonable to me for handling this flowing system. His method addresses the critical period when demand exceeds supply. I have reworked Balleau's impact analyses, however, to reflect the flow and drawdown discussed in the two preceding sections.

Using Balleau's flow reduction values (which I think are too high), but a maximum flow of $1.14 \mathrm{cfs}$ thermal flow down the Jemez River to the Jemez Canyon Dam, and the acreage affected by $1 \mathrm{cfs},{ }^{*}$ the acreages affected in the Jemez River valley at various times are reported in Table III. The acreage affected at the 30th year is about one-third that determined by Balleau because of the different total thermal flows used: $1.14 \mathrm{cfs}$ vs $3.5 \mathrm{cfs}$. Using the large water tower model (15-mile diameter and $0.3 \%$ water storage) to predict a flow reduction, instead of using Balleau's values, gives the acreage affected as reported in Table IV. The average number of Jemez River valley acres affected in the 30th year will be 14.4 acres. This is one-fourteenth the number (208) that Balleau determined, but the same as that in the EIS for a smaller reduction in flow. The validity of any of these values, of course, rests on the accuracy of the flow and depletion data, which must, therefore, be accurately determined.

Irrigation water lost to lands outside the Jemez River valley does not seem to be addressed by WRA or Balleau. Presumably the WRA evaluation assumes that all the Valles Caldera thermal flow goes down the Jemez River. Balleau's evaluation seems concerned only about the Jemez River valley Indians. Using the large water tower model (15-mile diameter and $0.3 \%$ water storage) to obtain figures, Table $\mathrm{V}$ reports the water lost to Rio Grande customers. Approximately 33 acre-ft of water will be lost to Rio Grande customers per month during the irrigation season in the 30th year. Evaluations of water impacts of the hydrothermal project should take into account these losses as well as any reduction in salt level.

*I have not questioned the irrigation acreage to which Balleau claims the Indians have legal rights. This seems a matter for the courts. 
TABLE III

JEMEZ IRRIGATION ACREAGE DEPENDENT ON HYDROTHERMAL FLOW

(Using Balleau's Flow Reduction Values)

\begin{tabular}{|c|c|c|c|c|c|c|c|}
\hline \multirow[b]{2}{*}{ Year } & \multicolumn{2}{|c|}{ Flow Decrease } & \multicolumn{5}{|c|}{ Jemez Acreage Affected by Flowa } \\
\hline & $(\%)^{b}$ & (cfs) & June & July & Aug & Sept & Average \\
\hline - & 0 & $1.0^{\mathrm{c}, \mathrm{d}}$ & $56.0^{\mathrm{c}}$ & $59.7^{\mathfrak{c}}$ & $83.0^{\mathrm{c}}$ & $118.0^{c}$ & $79.2^{c}$ \\
\hline 1 & 8 & 0.091 & 5.1 & 5.5 & 7.6 & 11.0 & 7.3 \\
\hline 5 & 42 & 0.48 & 26.7 & 28.6 & 39.7 & 56.4 & 37.9 \\
\hline 10 & 58 & 0.66 & 37.0 & 39.5 & 54.9 & 78.1 & 52.4 \\
\hline 20 & 70 & 0.80 & 44.9 & 47.9 & 66.6 & 94.7 & 63.5 \\
\hline 30 & 75 & 0.86 & 48.1 & 51.2 & 71.2 & 101.3 & 68.0 \\
\hline - & 100 & $1.14(\max )$ & 63.9 & 68.1 & 94.6 & 134.5 & $90.4(\max )$ \\
\hline
\end{tabular}

After Williams, based on maximum hydrothermal flow of $0.81 \mathrm{cfs}$.

bAfter DOI/Balleau, page 8.

After DOI/Balleau, Table II.

'One cfs produces 60.4 acre-ft of water per month.

TABLE IV

JEMEZ IRRIGATION ACREAGE DEPENDENT ON HYDROTHERMAL FLOW

(Using 15-Mile Diameter, 0.3\% Water Storage, Water Tower Model)

\begin{tabular}{|c|c|c|c|c|c|c|c|}
\hline \multirow[b]{2}{*}{ Year } & \multicolumn{2}{|c|}{ Flow Decrease } & \multicolumn{5}{|c|}{ Jemez Acreage Affected by Flow ${ }^{\star}$} \\
\hline & $(\%)^{b}$ & (cfs) & June & July & Aug & Sept & Average \\
\hline- & 0 & $1.0^{c, d}$ & $56.0^{c}$ & $59.7^{c}$ & $83.0^{c}$ & $118.0^{c}$ & $79.2^{c}$ \\
\hline 1 & 1 & 0.011 & 0.6 & 0.7 & 0.9 & 1.3 & 0.9 \\
\hline 5 & 2.5 & 0.029 & 1.6 & 1.7 & 2.4 & 3.4 & 2.3 \\
\hline 10 & 6 & 0.068 & 3.8 & 4.1 & 5.7 & 8.1 & 5.4 \\
\hline 20 & 11 & 0.125 & 7.0 & 7.5 & 10.4 & 14.8 & 9.9 \\
\hline 30 & 16 & 0.182 & 10.2 & 10.9 & 15.1 & 21.5 & 14.4 \\
\hline - & 100 & $1.14(\max )$ & 63.9 & 68.1 & 94.6 & 134.5 & $90.4(\max )$ \\
\hline
\end{tabular}

after Williams, based on maximum hydrothermal flow of $0.81 \mathrm{cfs}$.

bAfter Williams, Fig. 15.

cAfter DOI/Balleau, Table II.

dOne cfs produces 60.4 acre-ft of water per month. 
TABLE V

\section{WATER LOST YEARLY TO RIO GRANDE CUSTOMERS}

(Using 15-Mile Diameter, 0.3\% Water Storage, Water Tower Model)

\begin{tabular}{|c|c|c|c|}
\hline \multirow[b]{2}{*}{ Year } & \multirow{2}{*}{$\begin{array}{l}\text { Decreased } \\
\text { Flow (\%) }\end{array}$} & \multicolumn{2}{|c|}{ Acre-Ft Lost ${ }^{\mathrm{a}}$} \\
\hline & & Total $^{c}$ & Per Irrigation Month \\
\hline 1 & 1 & 14.4 & 2.1 \\
\hline 5 & 2.5 & 36.1 & 5.2 \\
\hline 10 & 6 & 86.5 & 12.4 \\
\hline 20 & 11 & 159 & 22.7 \\
\hline 30 & 16 & 231 & 33.0 \\
\hline- & 100 & & \\
\hline
\end{tabular}

\section{v. COMMENTS}

The extreme difference in the anticipated hydrological effects predicted by the two expert treatments discussed herein points out the uncertainty of proper hydrological treatment and the uncertainty in the data needed to make the evaluations. The important parameters seem to be

- water flow contributions from a hydrothermal reservoir to the local and regional fresh water systems,

- depletion of these hydrothermal contributions, and

- cropland tradeoff methodology.

Balleau presents a more complete hydrothermal flow contribution than does WRA, which addresses only that contribution down the Jemez River to Jemez Springs. Balleau's treatment is not precise, however. His primary. difficulty seems to be a large perturbation caused by using data taken below an evaporation area (the Jemez Canyon Dam). Elemental analyses (preferably five or so) were used by each group, and this method appears to be a good, straightforward one if large flow restrictions are not present. A method for handling dams and other stagnation points in a stream flow system should be employed. If such a method is not available, it should be developed. Evaporation needs to be considered, as do subsurface influx and outflow. The total range between the high (Balleau) and low (WRA) hydrothermal contribution is only 10 -fold even without such considerations. The water contribution area needs only refining and more careful attention, not revamping.

The depletion of hydrothermal flow is an area of little agreement and in need of significant overhauling. Balleau reports that only $3 \mathrm{yr}$ are needed to produce a $20 \%$ reduction in hydrothermal supplies to the Jemez River waterways whereas WRA claims that such a reduction will take hundreds or thousands of years. Balleau's results seem extreme and about what I would expect at a production well with a useful life of $30 \mathrm{yr}$. He does recognize, however, that all the water present is not pumpable. The WRA results seem to be too moderate and encompass too large a reservoir. Major needs in this area are

- a good working hydrological model or approach,

- reservoir dimensions and physical arrangement,

- reservoir interconnections with the pumping site, and

- water storage.

Transmissivity should need refining only, as the two treatments use values ( $146 \mathrm{ft}^{2} /$ day and $366 \mathrm{ft}^{2} /$ day) that differ by just a factor of 2.5. Eventual effects (long term) and temporal effects should be addressed, if possible.

The evaluation of irrigated cropland losses needs a proper methodology. Croplands above any collection point (dam) will have a synchronous effect on flow depletion and thus on land watering. Croplands below such a point will be cumulatively affected. The synchronous effect will be relatively larger as the effect is not averaged over the entire year. Regional effects, as well as special interests, should be considered. If water pollution from salts becomes a problem, reduced thermal input could help remedy it. The Jemez River can occasionally approach the water standards for chloride ions at a point just above where the Rio Guadalupe enters the Jemez River. This is caused primarily by thermal spring discharges in Jemez Canyon and around Jemez Springs. Generally, special caution is needed when relating acreage of highly watered cropland to depletion in water levels.

The solutions to the needs presented above will not come easily. The two treatments discussed here were not, in fact, done quickly and without thought. Each, however, leads to a more palatable conclusion for its benefactors than for the opposition. An exacting and impartial method of evaluation appears needed. Such a treatment should also form the basis for performing future evaluations. 


\section{ACKNOWLEDGMENTS}

I thank my MST-7 group and MST Division for providing the support and encouragement to publish this report. I especially appreciated the valuable comments made by Fraser Goff and the photos and data provided by the US Army Corps of Engineers.

\section{REFERENCES}

1. J. R. Erickson, "Hydrology-Jemez Mountains, New Mexico," written by Water Resources Associates, Inc., for Union Geothermal Division of Union Oil Company (March 1977).

2. "Geothermal Demonstration Program, 50-MW Power Plant, Final Environmental Impact Statement," DOE/EIS-0049 (January 1980).

3. W. P. Balleau, "Geothermal Hydrology at Jemez Mountains-Ion Balance and Flow Depletion," written for DOI/BIA (March 1980).

4. Fraser Goff, Tamsin McCormick, Pat E. Trujillo, Jr., Dale Counce, and C. O. Grigsby, "Geochemical Data for 95 Thermal and Nonthermal Waters of the Valles Caldera-Southern Jemez Mountains Region, New Mexico," Los Alamos National Laboratory report LA-9367-OBES (May 1982).

5. Frank W. Trainer, "Geohydrology Data from the Jemez Mountains and Vicinity, North-Central New Mexico," US Geological Survey Water Resources Investigation report USGS/WRI 77-131 (1978).

6. Frank W. Trainer, "Mixing of Thermal and Nonthermal Waters in the Margin of the Rio Grande Rift, Jemez Mountains, New Mexico," New Mexico Geological Society Guidebook, 26th Field Conference (1975).

7. Fraser Goff and Charles O. Grigsby, "Valles Caldera Geothermal Systems, New Mexico, USA," Journal of Hydrology 56, 119 (1982).

8. Fraser E. Goff, Charles O. Grigsby, Pat E. Trujillo, Jr., Dale Counce, and Andrea Kron, "Geology, Water Geochemistry and Geothermal Potential of the Jemez Springs Area, Cañon de San Diego, New Mexico," Journal of Volcanology and Geothermal Research 10, 227 (1981).
9. Frank W. Trainer, “Ground Water in the Southwestern Part of the Jemez Mountains Volcanic Region, New Mexico," New Mexico Geological Society Guidebook, 25th Field Conference (1974).

10. Roy L. Griggs, "Geology and Ground Water Resources of the Los Alamos Area of New Mexico," US Geological Survey Water-Supply Paper No. 1753 (1964).

11. C. S. Conover, C. W. Theis, and R. L. Griggs, "Geology and Hydrology of Valles Grande and Valle Toledo, Sandoval County, New Mexico," US Geological Survey Water-Supply Paper No. 1619-Y (1963).

12. W. Purtymun and S. Johanson, "General Geohydrology of the Pajarito Plateau," New Mexico Geological Society Guidebook, 25th Field Conference (1974).

13. Fraser E. Goff and Suzanne Sayer, "A Geothermal Investigation of Spring and Well Waters of the Los Alamos Region, New Mexico," Los Alamos National Laboratory report LA-8326-MS (1980).

14. Margaret Gary, Robert McAfee, Jr., and Carol L. Wolf(Eds.), "Glossary of Geology," American Geological Institute, Washington, DC (1972).

15. David Keith Todd, Ground Water Hydrology (John Wiley and Sons, Inc., New York, 1959).

\section{POSTSCRIPT}

After the writing of this report but before its publication, several other articles concerning the Jemez River system and the Valles Caldera were published. They are listed below. The most notable of them, with regard to this report, is the one listed first, by Balleau and his coauthors, who discuss modeling of the Baca geothermal area. Interestingly, they also treat the Baca geothermal water problem with an "equivalent porous media" approach, as used herein, in spite of the immense complexity of the region. They still believe the 30-yr impact will be large.

1. C. R. Faust, J. W. Mercer, S. D. Thomas, and W. P. Balleau, "Quantitative Analysis of Existing Conditions and Production Strategies for the Baca Geothermal System, New Mexico," Water Resources Research 20 (5), 601 (1984). 
2. A. F. White, J. M. Delany, A. Truesdale, C. Janik, F. Goff, and H. Crecraft, "Fluid Chemistry of the Baca Geothermal Field, Valles Caldera, New Mexico," New Mexico Geological Society Guidebook, 35th Field Conference, Rio Grande Rift, Northern New Mexico (1984).

3. F. W. Trainer, "Thermal Mineral Springs in Cañon de San Diego as a Window into Valles Caldera, New
Mexico," New Mexico Geological Society Guidebook, 35th Field Conference, Rio Grande Rift, Northern New Mexico (1984).

4. F. Goff, J. Gardner, R. Vidale, and R. Charles, "Geochemistry and Isotopes of Fluids from Sulfur Springs, Valles Caldera, New Mexico," Journal of Volcanology and Geothermal Research 23, 273 (1985).

\section{APPENDIX}

\section{JEMEZ CANYON DAM AND RESERVOIR*}

The Jemez Canyon Dam is located on the Jemez River, 2 miles north of the river's confluence with the Rio Grande and about 6 miles north of Bernalillo, New Mexico (see Fig. 3). An aerial survey taken in January 1975 (Fig. A-1) shows that the basin behind the dam is long (>11 miles), broad (sometimes $>1 / 2$ mile), and extremely flat. From the contour map (Fig. A-2), the basin is seen to drop only $0.33 \%$ [ $80 \mathrm{ft}$ in $24200 \mathrm{ft}$ (4.5 mi)] just behind the dam.

Although designed as a flood control dam and operated mainly in a flow-through manner, the Jemez Canyon Dam has often had a water pool behind it. Figure A-3 shows the times (from 1954 to 1975) during which a pool occurred. These data are broken down into two time periods (Table A-I). During the period 1955 to 1965 , a pool occurred about $46 \%$ of the time; from 1966-1974, it occurred about $31 \%$ of the time. Except for four periods, the pool was rather small and extended less than one-half mile behind the dam. The highest level during this period (1958) created a pool extending about 4 miles back. A permanent pool was established behind the dam in March 1979 (see Fig. A-4). This pool extends about 1 mile back. The stream feeding the pool has been observed by the Corps of Engineers personnel to meander all over the broad, fiat area.
TABLE A-I

\section{OCCURRENCE OF A WATER POOL BEHIND THE DAM}

\begin{tabular}{ccccc} 
Year & $\begin{array}{c}\text { Fraction of Year } \\
\text { Pool Observed }\end{array}$ & $\frac{\text { Year }}{1966}$ & $\begin{array}{c}\text { Fraction of Year } \\
\text { Pool Observed }\end{array}$ \\
\hline 1955 & $\frac{0.42}{1956}$ & 0.34 & 1967 & 0.23 \\
1957 & 0.66 & 1968 & 0.17 \\
1958 & 0.47 & 1969 & 0.41 \\
1959 & 0.50 & 1970 & 0.45 \\
1960 & 0.44 & 1971 & 0.41 \\
1961 & 0.50 & 1972 & 0.17 \\
1962 & 0.34 & 1973 & 0.25 \\
1963 & 0.44 & 1974 & 0.48 \\
1964 & 0.42 & & 0.22 \\
1965 & 0.48 & & \\
\hline 11 yrs & $\bar{x}=0.46$ & 9 yrs & $\bar{x}=0.31$ \\
& $\sigma=0.09$ & & $\sigma=0.13$
\end{tabular}

*The data presented in this Appendix were obtained from the Corps of Engineers, US Army, Albuquerque, New Mexico. The author is grateful to Jasper Coomes, Dick Kreiner, and Kim Zahm for providing them. 


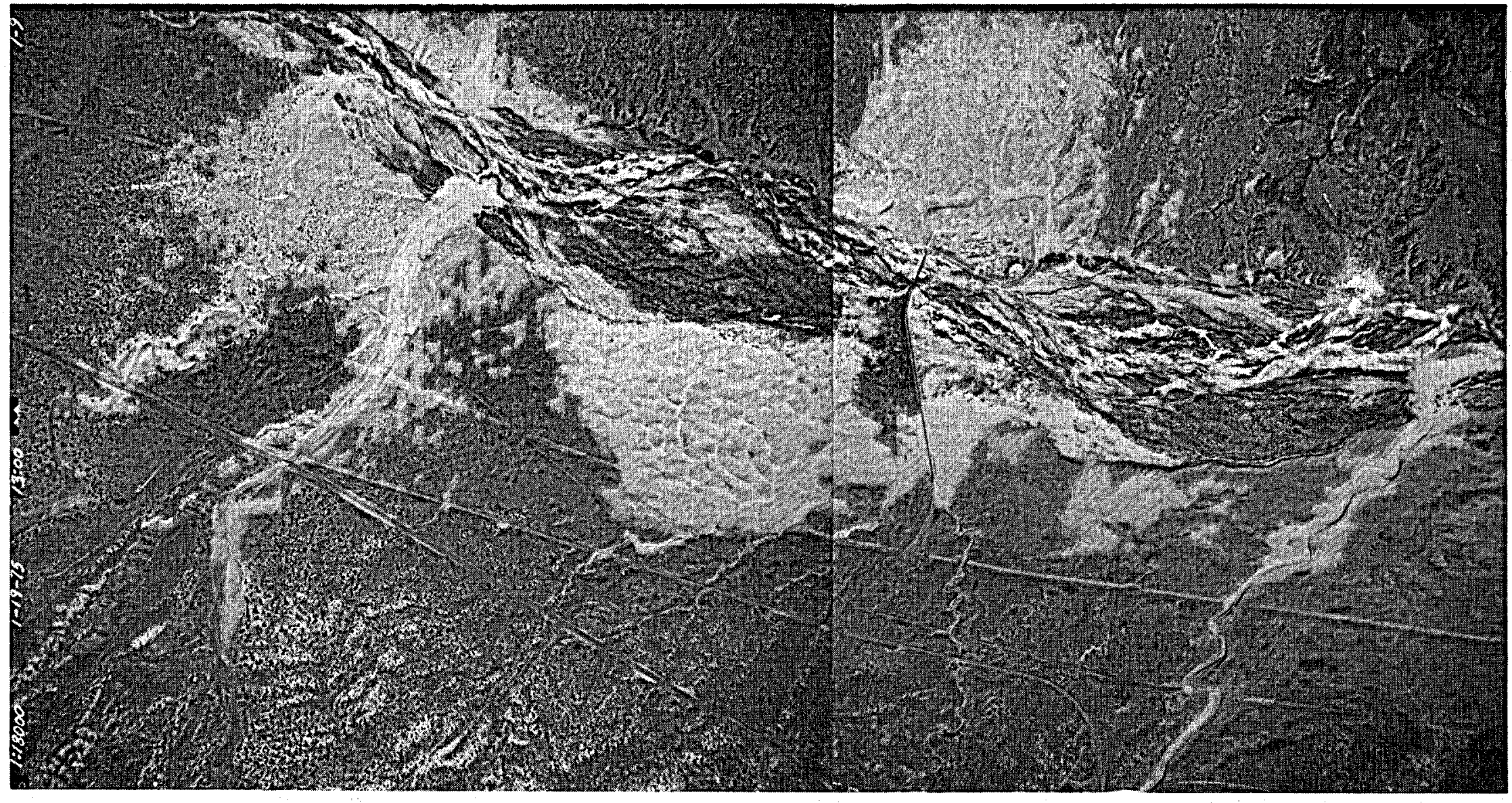

Fig. A-1a. Aerial photograph of Jemez Canyon Dam-area just upstream (left) of that in Fig. A-1b and looking north. 


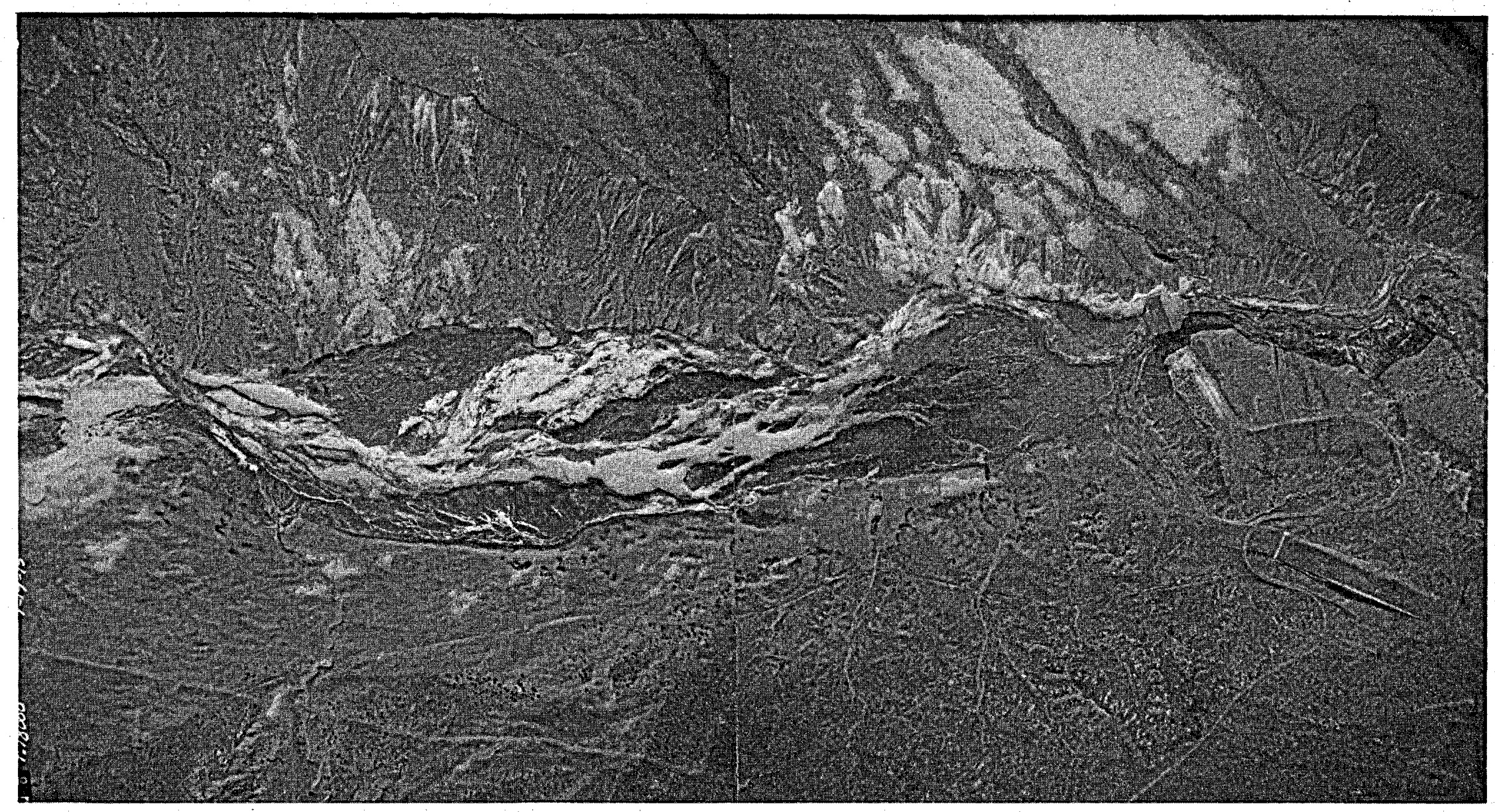

Fig. A-1b. Aerial photograph of Jemez Canyon Dam—area around dam looking north (taken January 19, 1975). 


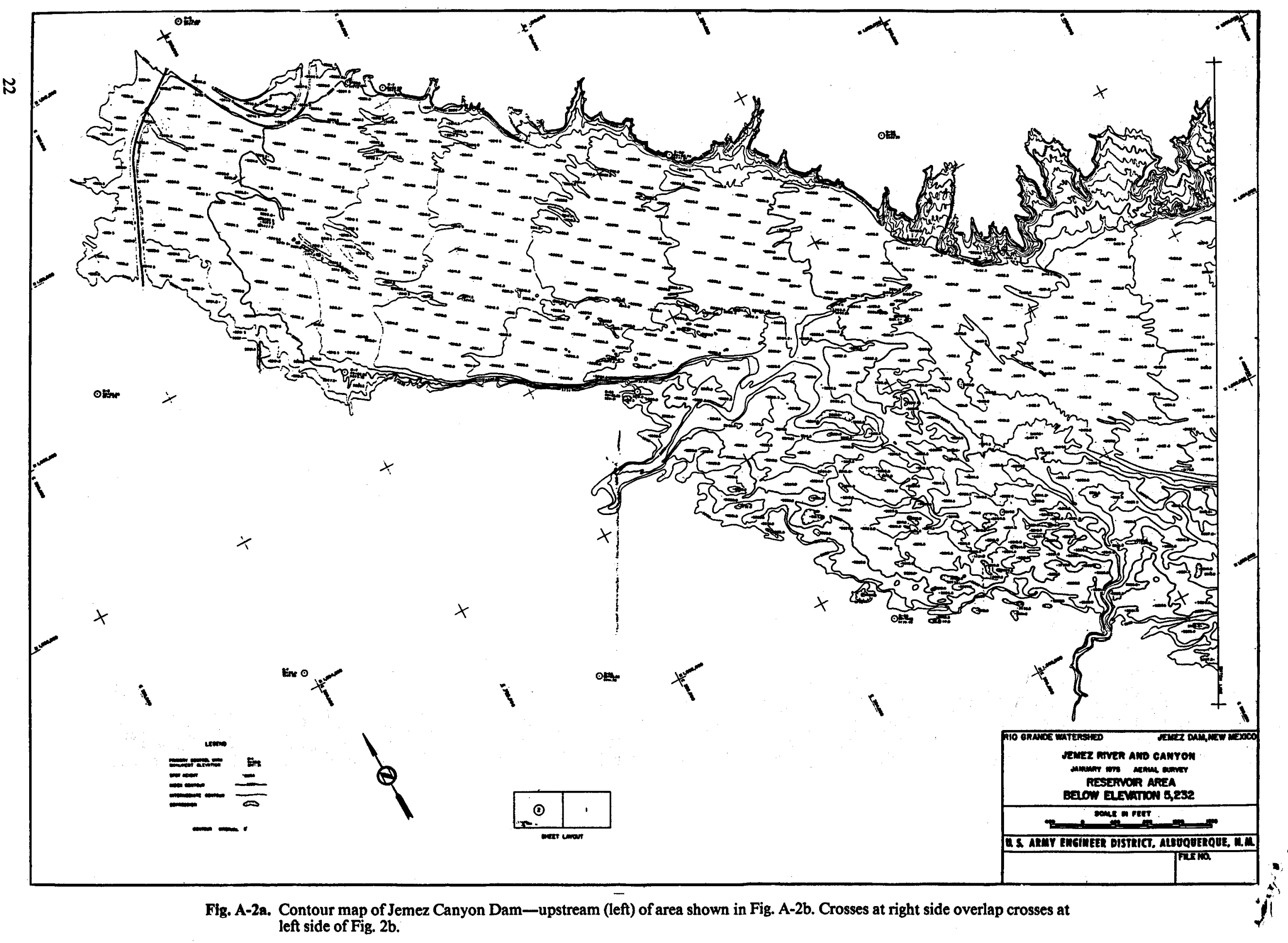




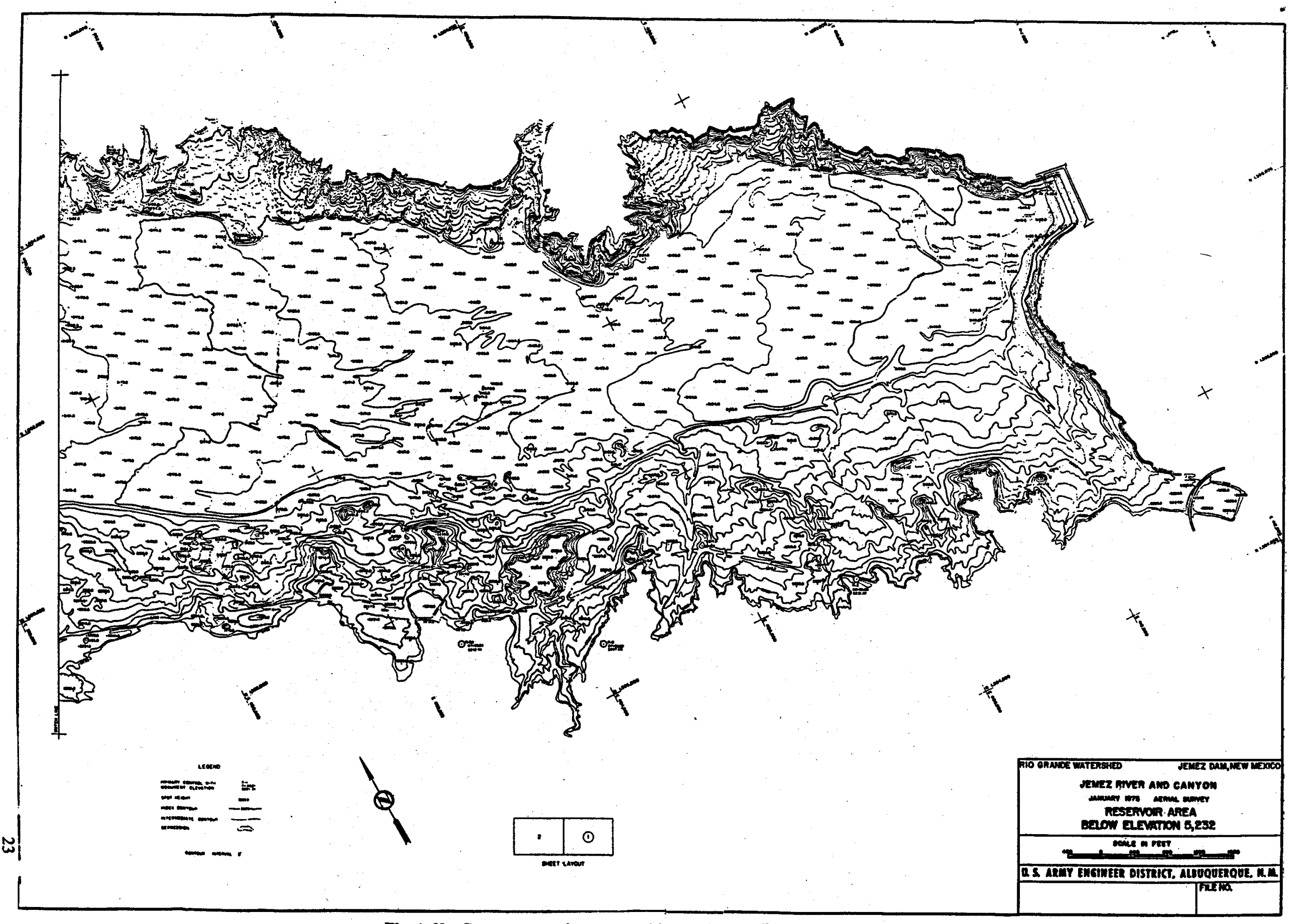

Fig. A-2b. Contour map of area around Jemez Canyon Dam (January 1975). 


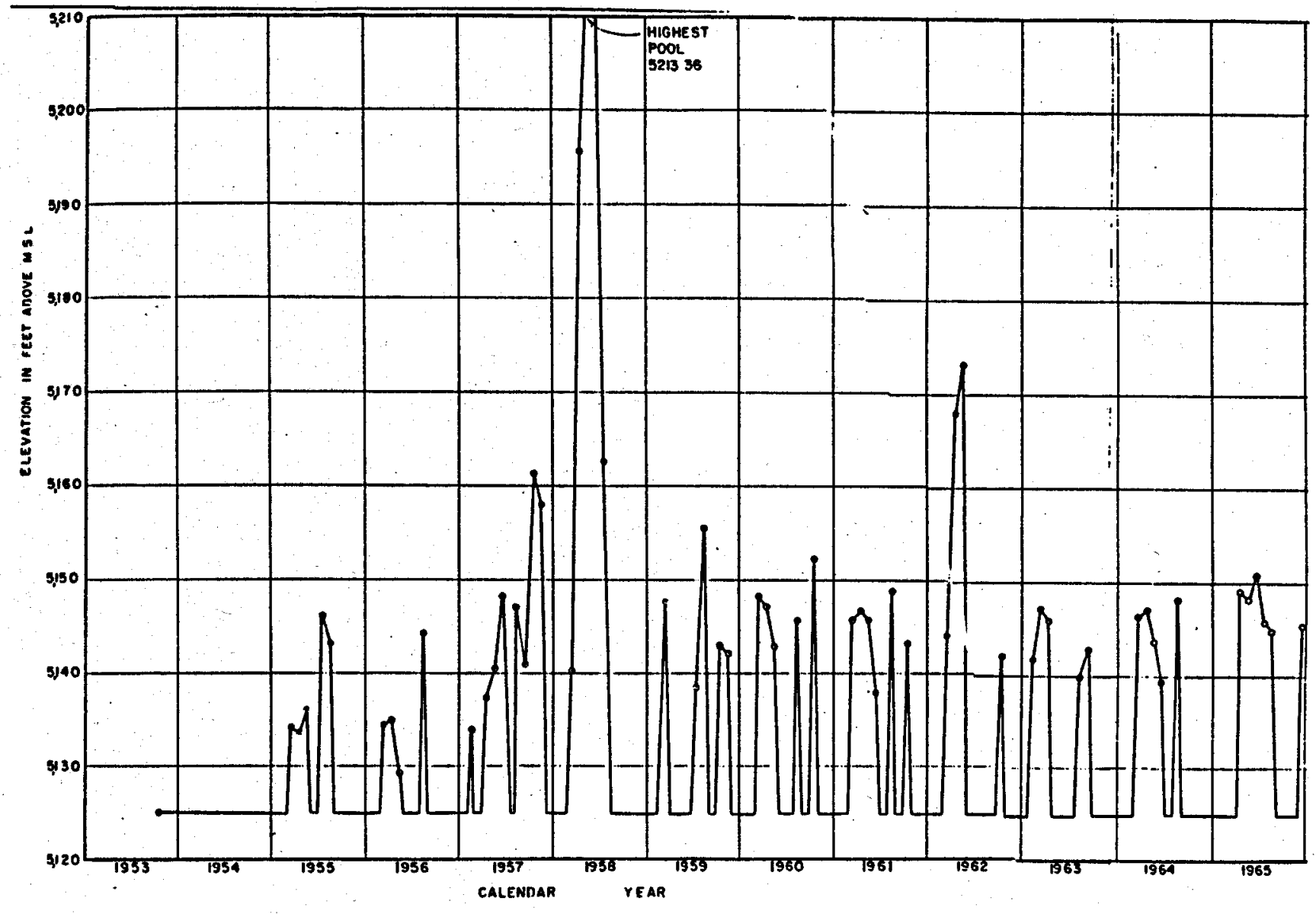

Fig. A-3a. Height and duration of water pools behind the Jemez Canyon Dam from 1953 to 1965. 


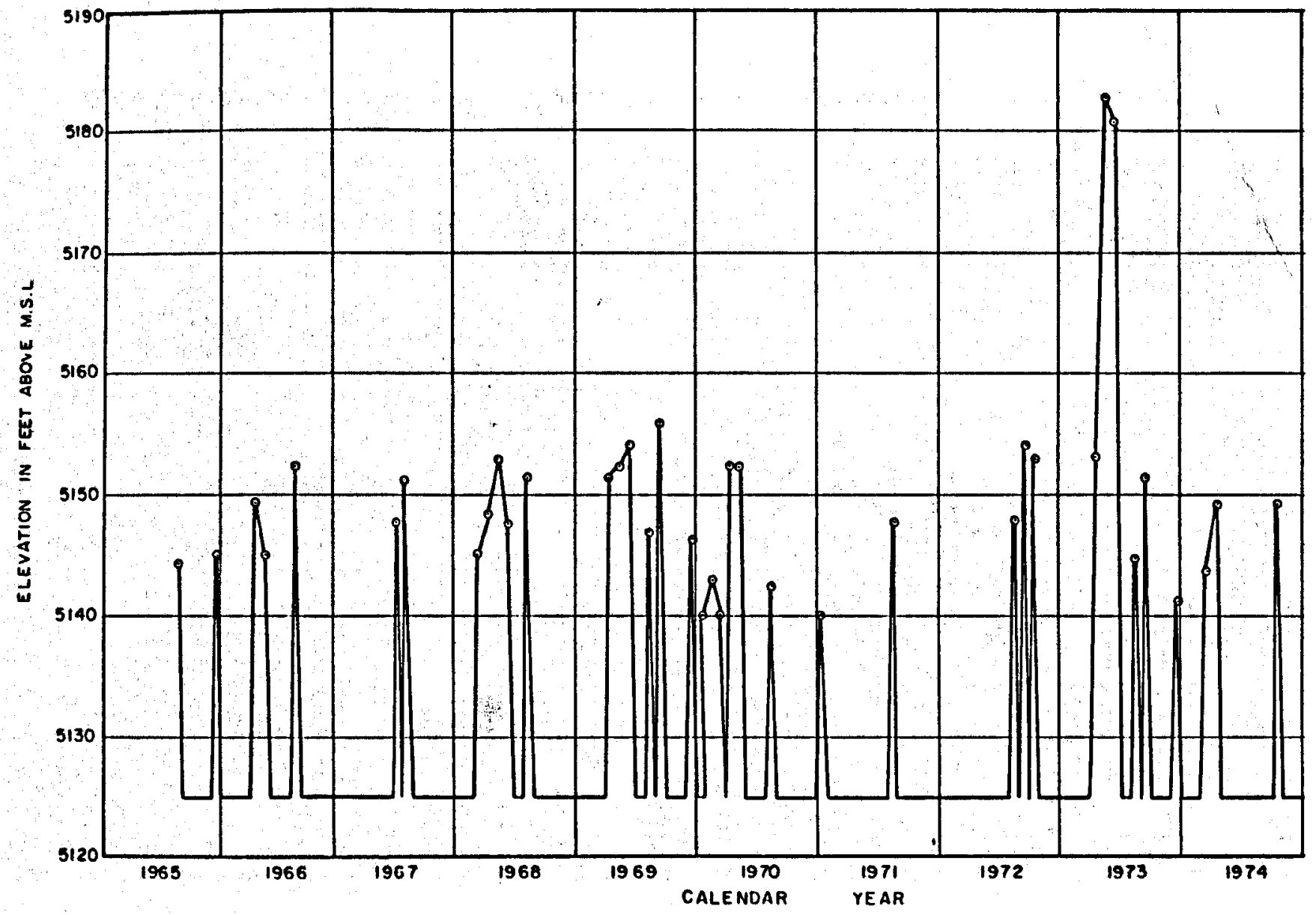

Fig. A-3b. Height and duration of water pools behind the Jemez Canyon Dam from 1965 to 1974. 


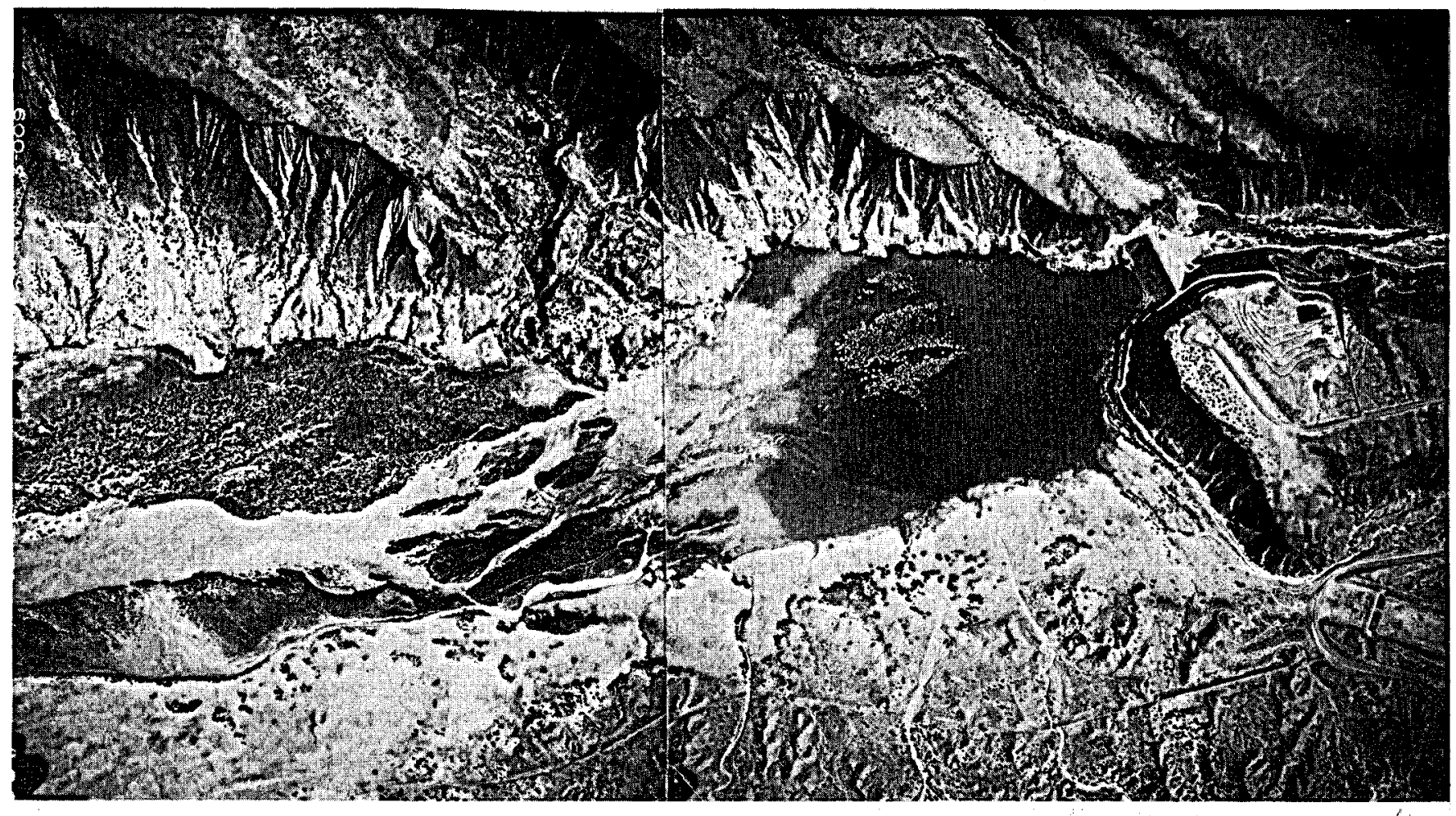

Fig. A-4. Photograph of permanent pool, established in March 1979, behind Jemez Canyon Dam looking north. 